\title{
Inactivation and risk control of pathogenic microorganisms in municipal sludge treatment: A review
}

\author{
Mengtian Li ${ }^{1,2}$, Ge Song ${ }^{1,2}$, Ruiping Liu $(\bowtie)^{3}$, Xia Huang ${ }^{4}$, Huijuan Liu ${ }^{3}$ \\ 1 State Key Laboratory of Environmental Aquatic Chemistry, Research Center for Eco-Environmental Sciences, Chinese Academy of Sciences, \\ Beijing 100085, China \\ 2 University of Chinese Academy of Sciences, Beijing 100049, China \\ 3 Center for Water and Ecology, School of Environment, Tsinghua University, Beijing 100084, China \\ 4 School of Environment, Tsinghua University, Beijing 100084, China
}

\begin{abstract}
H I G H L I G H T S
- Diversity and detection methods of pathogenic microorganisms in sludge.

- Control performance of sludge treatment processes on pathogenic microorganisms.

- Risk of pathogen exposure in sludge treatment and land application.
\end{abstract}

\section{A R T I C L E I N F O}

\section{Article history:}

Received 23 March 2021

Revised 28 June 2021

Accepted 12 July 2021

Available online 25 September 2021

\section{Keywords:}

Sludge treatment

Pathogenic microorganisms

Inactivation mechanisms

Exposure risks

Land application

\section{GRAPHIC A B T RACT}

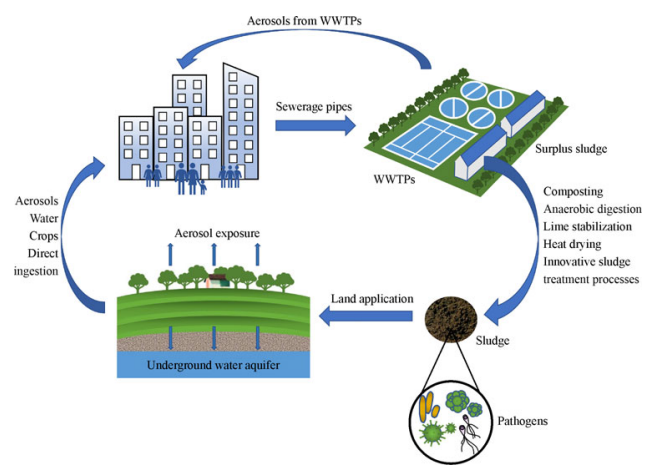

\section{A B S T R A C T}

The rapid global spread of coronavirus disease 2019 (COVID-19) has promoted concern over human pathogens and their significant threats to public health security. The monitoring and control of human pathogens in public sanitation and health facilities are of great importance. Excessive sludge is an inevitable byproduct of sewage that contains human and animal feces in wastewater treatment plants (WWTPs). It is an important sink of different pollutants and pathogens, and the proper treatment and disposal of sludge are important to minimize potential risks to the environment and public health. However, there is a lack of comprehensive analysis of the diversity, exposure risks, assessment methods and inactivation techniques of pathogenic microorganisms in sludge. Based on this consideration, this review summarizes the control performance of pathogenic microorganisms such as enterovirus, Salmonella spp., and Escherichia coli by different sludge treatment technologies, including composting, anaerobic digestion, aerobic digestion, and microwave irradiation, and the mechanisms of pathogenic microorganism inactivation in sludge treatment processes are discussed. Additionally, this study reviews the diversity, detection methods, and exposure risks of pathogenic microorganisms in sludge. This review advances the quantitative assessment of pathogenic microorganism risks involved in sludge reuse and is practically valuable to optimize the treatment and disposal of sludge for pathogenic microorganism control.

(C) Higher Education Press 2021

\section{Introduction}

The treatment of urban sewage inevitably produces plentiful sludge as a byproduct (Hu et al., 2019). The

$\triangle$ Corresponding author

E-mail: rpliu@tsinghua.edu.cn sludge contains various pollutants, such as infectious pathogens, heavy metals, and micro-organic pollutants (Romdhana et al., 2009; Yang et al., 2015). Although sludge is the main sink of pathogenic microorganisms in WWTPs and a potential source of microorganisms in the environment (Fig. 1), it is also an important source of organic matter and nitrogen- and phosphorus-containing nutrients. Reuse of sludge is the general trend. To date, 
many wastewater treatment plants (WWTPs) install sludge treatment units, and treated sludge may be used as fertilizers and nutritional soils to improve fertility. In this case, pathogenic microorganisms should be carefully inactivated and controlled to minimize potential risks to water bodies, soils, and human health as much as possible (Pritchard et al., 2010).

The pathogens in sewage and WWTP effluents have been widely reported to threaten the health of humans and animals (Schöniger-Hekele et al., 2007; Sutherland et al., 2010; Boehm et al., 2018). However, relatively less attention has been given to the occurrence, concentrations, and risks of aerosol transmission and epidemiology of various pathogens in sludge (Viau et al., 2011). This makes considering the annual production of large amounts of sludge an important global issue. For example, in China, WWTPs produced 67.65 million tons of sludge with a moisture content of $80 \%$ in 2018 , and the annual growth rate was expected to be in the range of $5 \%$ to $8 \%$ (Dai et al., 2020).

To achieve proper sludge treatment, different countries and regions have issued standards and documents (Table 1). However, most regulations on pathogenic microorganism control are dependent on several pathogens, such as coliforms and enteroviruses, and the risk of pathogen transmission via sludge can hardly be well characterized (Viau et al., 2011; Kelessidis and Stasinakis, 2012). In addition, the risk of pathogenic microorganisms carrying antibiotic resistance genes (ARGs) and thus having antibiotic resistance has not been considered by standards and regulations. Regulation standards and detection methods need to be updated and improved (Yang et al., 2015). It is important to promise a theoretical and technical basis to guarantee the update of relevant standards. In China, there is no virus indicator in the relevant standards for municipal sludge treatment and sludge agricultural use.
Recently, the risks of SARS-CoV-2 spreading through fecal-oral and fecal-respiratory transmission have received great attention, but transmission and spread via sludge is far from well-illustrated (Carraturo et al., 2020; Foladori et al., 2020; Li et al., 2020b). A recent study showed that because sludge contains more virus particles and longer residence times, it is easier to detect SARS-CoV-2 in sludge than in sewage (Balboa et al., 2021). Obviously, routine detection cannot adequately represent the risk of special pathogens in sludge during a particular period. In this case, the treatment and disposal of sludge concerning pathogenic microorganism control should be given more attention than before.

Conventional sludge treatment methods include anaerobic digestion, aerobic digestion, composting, lime stabilization, etc. (Yang et al., 2015; Tong et al., 2019; Major et al., 2020). Disposal methods include sanitary landfills, incineration, land application, production of building materials, etc. (Yang et al., 2015). Recently, resource reclamation and energy harvesting have been an essential focus in the process of upgrading existing WWTPs, and land application is an important way to reuse sludge. The inactivation efficiency of pathogenic microorganisms is largely dependent on the different physical, chemical, and biological processes (Kelessidis and Stasinakis, 2012; Dauknys et al., 2020; Jin et al., 2020). This strategy may potentially minimize potential pathogenic risks by reducing the sludge pathogenic load with optimized temperature, $\mathrm{pH}$, residence time and other conditions (Goberna et al., 2018). To achieve promising sludge sanitation for land application, combined processes with two or more units are expected to be implemented; however, there is still a lack of sufficient data to propose feasible processes and optimized strategies to control pathogenic microorganisms.

Based on these considerations, this review aims to

Table 1 Pathogen requirements for sludge applied to land in China, the United States and the European Union

\begin{tabular}{|c|c|c|c|c|c|c|c|}
\hline \multirow{2}{*}{$\begin{array}{l}\text { Countries } \\
\text { and } \\
\text { regions }\end{array}$} & \multirow{2}{*}{$\begin{array}{l}\text { Type of } \\
\text { sludge }\end{array}$} & \multicolumn{5}{|l|}{ Indicator pathogens } & \multirow[b]{2}{*}{ Standards or documents } \\
\hline & & Fecal coliforms & $\begin{array}{l}\text { Clostridium } \\
\text { perfringens }\end{array}$ & Helminth ova & Salmonella & Enteric viruses & \\
\hline China & $\begin{array}{l}\text { Agricultural } \\
\text { sludge }\end{array}$ & $\begin{array}{l}\text { Colititer is not less } \\
\text { than } 0.01\end{array}$ & - & $\begin{array}{l}\text { Mortality of } \\
\text { Ascaris eggs is } \\
\text { not less than } 95 \%\end{array}$ & - & - & $\begin{array}{l}\text { Control standards of pollutants } \\
\text { in sludge for agricultural use } \\
(2018)\end{array}$ \\
\hline $\begin{array}{l}\text { United } \\
\text { States }\end{array}$ & Class A & $\begin{array}{l}\text { Less than } 1000 \\
\text { MPN per gram of } \\
\text { total solids (dry } \\
\text { weight basis) }\end{array}$ & - & $\begin{array}{l}\text { The alternative: } \\
\text { Less than } 1 \\
\text { viable helminth } \\
\text { ova/4 grams of } \\
\text { total solids (dry } \\
\text { weight basis) }\end{array}$ & $\begin{array}{l}\text { Less than } 3 \text { MPN } \\
\text { per } 4 \text { grams of total } \\
\text { solids (dry weight } \\
\text { basis) }\end{array}$ & $\begin{array}{l}\text { The alternative: } \\
\text { Less than } 1 \text { PFU } \\
\text { per } 4 \text { grams of } \\
\text { total solids (dry } \\
\text { weight basis) }\end{array}$ & $\begin{array}{l}\text { USEPA, Environmental } \\
\text { Regulations and Technology: } \\
\text { Control of Pathogens and } \\
\text { Vector Attraction in Sewage } \\
\text { Sludge (2003). (Lloret et al., } \\
\text { 2012) }\end{array}$ \\
\hline $\begin{array}{l}\text { European } \\
\text { Union }\end{array}$ & $\begin{array}{l}\text { Sludge } \\
\text { applied to } \\
\text { land }\end{array}$ & $\begin{array}{l}\text { (Escherichia coli) } \\
99.99 \%(4 \mathrm{log}) \\
\text { reduction to less } \\
\text { than } 1 \times 10^{3} \\
\text { colony forming } \\
\text { units per gram } \\
\text { (dry weight) }\end{array}$ & $\begin{array}{l}\text { No more than } \\
3 \times 10^{3} \text { spores } \\
\text { per gram } \\
\text { (dry weight) }\end{array}$ & - & $\begin{array}{l}\text { No detectable } \\
\text { Salmonella spp. } \\
\text { in } 50 \mathrm{~g} \text { (wet weight) }\end{array}$ & - & $\begin{array}{l}\text { European Commission, } \\
\text { Proposal for a Directive of the } \\
\text { European parliament and of the } \\
\text { Council on the spreading of } \\
\text { sludge on land (2003). } \\
\text { (Lloret et al., 2012) }\end{array}$ \\
\hline
\end{tabular}




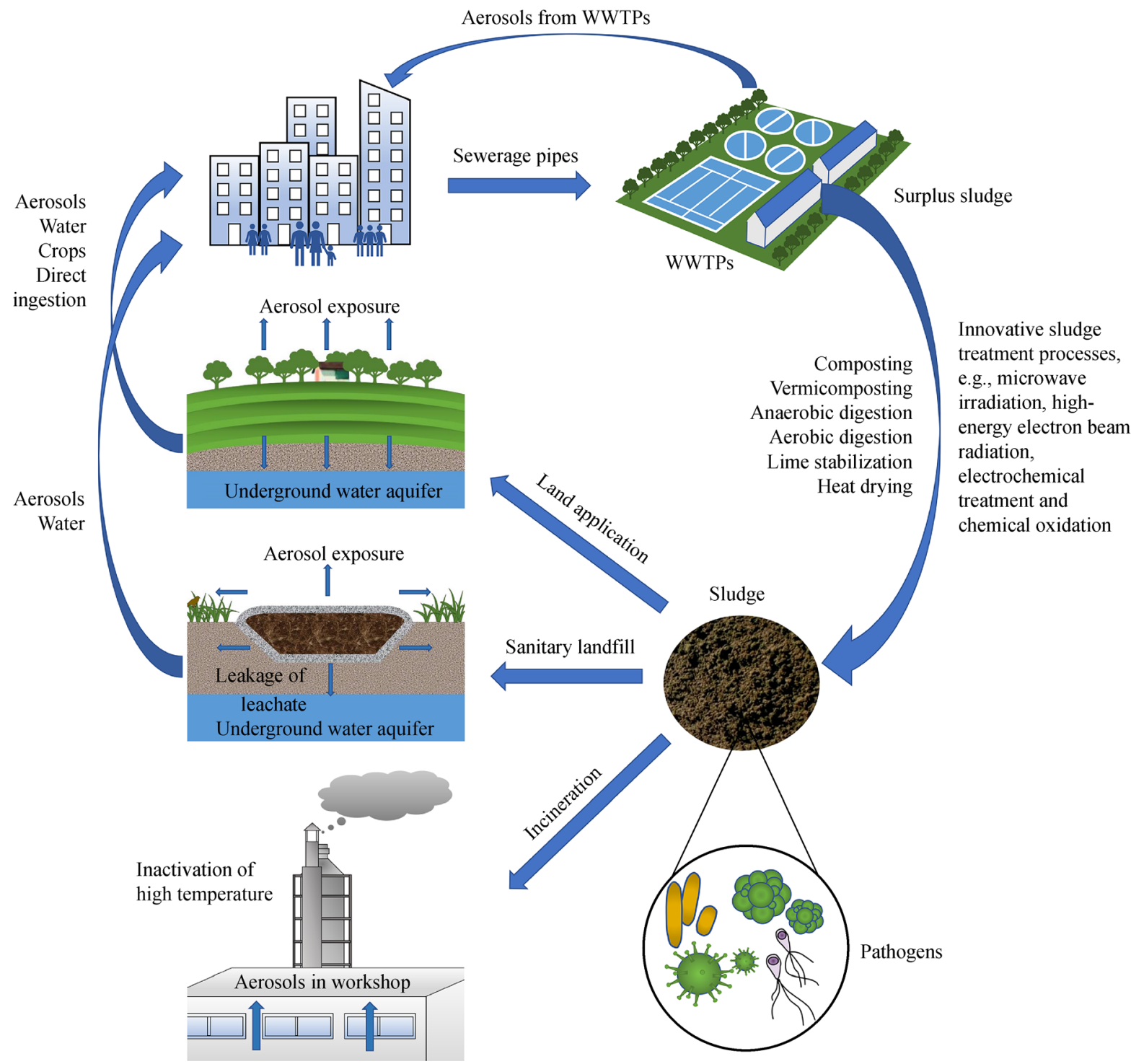

Fig. 1 Transfer and exposure pathways of pathogens involved in sludge treatment and disposal.

1) summarize the different species and methods of detecting pathogenic microorganisms in sludge; 2) investigate the efficiency and the dominant influencing factors involved in pathogen control by different sludge treatment processes; and 3) compare the advantages and disadvantageous of the currently used sludge treatment processes, as well as risks and potentials of sludge in land applications. This review provides insight into the treatment and disposal of sludge, and it is expected to be practically valuable with regard to pathogenic microorganism control in sludge.

\section{Detection, diversity, and potential risks of pathogenic microorganisms in the sludge}

Sewage sludge is reported to contain plentiful and diverse pathogenic microorganisms, such as pathogenic bacteria, viruses, and pathogenic protozoa (Ye and Zhang, 2011; Bibby and Peccia, 2013; Amoah et al., 2018). Understanding of pathogen diversity and exposure risk benefits the establishment of treatment strategies and standards for pathogen control, although it is rather difficult to detect all pathogenic microorganisms in sludge (Levantesi et al., 2015).

\subsection{Pathogenic bacteria}

Bacterial pathogens can survive and reproduce rapidly in suitable environments (Cai and Zhang, 2013), and most studies have focused on human pathogenic bacteria in sludge. Total coliforms, fecal coliforms and Salmonella are usually used as indicators in standards (Viau et al., 2011; Kelessidis and Stasinakis, 2012). Generally, the detection method of inoculating and cultivating cultivable bacteria has obvious limitations because the infectious doses vary 
greatly with different microorganism species (Shannon et al., 2007). Most bacteria in the environment are unculturable, which may cause deviations in test results ( $\mathrm{Lu}$ et al., 2015). The quantitative real-time polymerase chain reaction (qPCR) method has the advantages of faster speed, higher sensitivity, and better specificity than other traditional methods. It is not limited by the cultivability of microorganisms. The good evident strengths enabled it to be widely used to detect pathogens and viruses in many studies (Jyoti et al., 2011; Jebri et al., 2014; Jahne et al., 2020). With the rapid development of molecular biology technology, 16S rRNA amplicon sequencing and metagenomic sequencing technologies have also been applied to study sewage sludge (Ye and Zhang, 2011; Lu et al., 2015; Ju et al., 2017; Huang et al., 2018). These technologies enable in-depth research to discover new pathogens in sewage sludge, explore the relationship between pathogenic and nonpathogenic microorganisms, and analyze the co-occurrence of pathogens and ARGs (Ju et al., 2016). However, these methods also have some limitations. For example, the results of $16 \mathrm{~S}$ rRNA amplicon sequencing were strongly influenced by PCR primer choice and sample processing (Walker et al., 2015). Different DNA extraction methods may also cause significant differences in 16S rRNA gene sequencing (Kennedy et al., 2014). The selection of $16 \mathrm{~S}$ rRNA gene variable regions potentially leads to different amplification biases (Claesson et al., 2010), which infers the importance of the experimental verification of primers. In addition, depth bias is characteristic of metagenomic approaches and one factor that may cause differences between test results and cell culture tests. Thus, it is critical to decide the appropriate sequencing depth in metagenomic sequencing (Quince et al., 2017). For cultivable microorganisms, cell culture more easily detects low-level bacteria than large-scale molecular detection because of sequencing detection thresholds (Lagier et al., 2012). In analyzing the sequencing results, in addition to the 16S rRNA gene sequence database, the virulence factor database is also often used to study pathogens. Virulence factors (VFs) are applied not only to study the pathogenesis of human pathogens but also as pathogenic indicators for the detection of human bacterial pathogens. For example, Cai et al. studied the $16 \mathrm{~S}$ rRNA genes and the VF genes in AS, and Mycobacterium tuberculosis was reported to be the most dominant pathogen (Cai and Zhang, 2013). The use of these two databases may obtain more comprehensive results of pathogen diversity. The rapid development of metagenomic sequencing methods provides optimistic insight into the analysis of microbial diversity in sludge.

The US Environmental Protection Agency (USEPA) Office of Research and Development released information on the 24 types of pathogenic bacteria that may be found in Class B sludge: Legionella, Aeromonas, Bacillus, Listeria, Brucella, Campylobacter, Proteus, Pseudomonas, Coxiella, Clostridium, Mycobacterium, Escherichia,
Salmonella, Shigella, Citrobacter, Enterobacter, Serratia, Erysipelothrix, Staphylococcus, Klebsiella, Streptococcus, Francisella, Yersinia, and Vibrio (Lewis. and Gattie., 2002). In recent years, sequencing technology has continuously reported new pathogenic bacteria in sludge. $\mathrm{Li}$ et al. detected Collinsella aerofaciens, Eubacterium rectale, Streptococcus salivarius, and Vibrio mimicus, which were previously unreported in activated sludge (AS), and discovered Bacteroides vulgatus, E. rectale, $C$. aerofaciens, Streptococcus suis, and S. salivarius, which were previously unreported in anaerobic digestion sludge (ADS) (Li et al., 2015). Additionally, Ju et al. found that $C$. aerofaciens, Arcobacter butzleri, S. salivarius, E. rectale, Acinetobacter johnsonii and $S$. suis had high relative abundances in sludge digesters (Ju et al., 2016). It has been reported that Oligella urethralis, Aeromonas hydrophila, Aeromonas veronii, Mycobacterium smegmatis, Vibrio cholerae, and Pseudomonas putida have high relative abundances in AS (Zhang et al., 2021). Because more human bacterial pathogens were detected in the sludge, the risk of infection related to these pathogens should be taken seriously.

In addition, the risk of bacterial pathogens carrying ARGs leading to drug resistance cannot be ignored. The large-scale use of human and animal antibiotics may further complicate pathogenic risks to environments and humans, and ARGs in sludge have become a research hotspot (Zhang et al., 2009; Su et al., 2015; Liao et al., 2018). It has been reported that most ARGs in AS were carried by chromosomes (Zhang et al., 2021), which proved the possibility that bacterial pathogens in the sludge had antibiotic resistance. Bacterial pathogens may serve as ARG hosts, and the ARGs of multidrug and macrolidelincosamide-streptogramin are most likely to co-occur with human pathogens in sludge digesters (Ju et al., 2016). The hosting relationship is considered the most direct origin of ARG species co-occurring events (Ju et al., 2016), which undoubtedly increases the risks of resistant pathogens to environments and humans. In aerobic granular sludge (AGS) cultivation, abundant AGS may lead to the proliferation of inactivated ARGs (Li et al., 2020a), and much effort has been made to determine the potential hosts of ARGs in sludge and the corresponding control strategy.

\subsection{Viruses, pathogenic protozoa, and worms}

Due to the limitation on virus cultivability and the high detection costs, only the indicators of a few viruses were regulated by most standards for virus control. However, the exposure and environmental risks of viruses should be given more attention, especially during the coronavirus disease 2019 (COVID-19) pandemic. Somatic coliphages $(\mathrm{SOMCPH})$ can be used as a good indicator of viruses to illustrate their fate in the sludge treatment process (Mandilara et al., 2006); however, a single indicator can hardly provide full insight into the fate and risks of viruses. 
The diversity of human viruses in sludge is expected to be much higher than in wastewater and other environmental samples. Unfortunately, the methods used to explore the diversity of human viruses in sludge are far from well developed. The application of traditional cell culture methods is primarily restricted by their time consumption (Monpoeho et al., 2004), low adaptation to various virus species, and difficulty in culturing viruses such as noroviruses and astroviruses. (Sano et al., 2003). Immunological detection methods have the disadvantages of a high detection limit and low sensitivity (Graff et al., 1993). Metagenomic sequencing, gene chip, and qPCR methods can also be applied to virus detection (Soueidan et al., 2015; Li et al., 2016b; Zou et al., 2017). However, unlike bacterial pathogens, viruses have two types of genetic material, DNA and RNA. Viral metagenomics, which is more suitable for detecting viruses, has been widely used for viruses in environmental samples such as sewage and soil (Yu et al., 2019b; Guajardo-Leiva et al., 2020). However, its application in sludge is rare because people have paid less attention to viruses in sludge in the past. Compared to qPCR, metagenomic sequencing provided less sufficient data to promisingly represent human viruses (Bibby and Peccia, 2013). In addition, the viral genome database contains only a small portion of all viruses, and the genomes of most viruses remain to be studied.

Sludge may contain multiple viruses, such as astroviruses, norwalk viruses, hepatitis viruses, rotaviruses and enteroviruses (Wong et al., 2010; Prado et al., 2014; Lizasoain et al., 2018). With the continuous development of detection technologies, an increasing number of new viruses have been discovered in sludge, and virus-related databases have been updated accordingly. The risk of bacteriophages in sludge as a resistance gene carrier was also assessed, and the densities of the two resistance genes of blaTEM and sull in sludge phages were as high as 5.5 and $4.4 \log _{10}$ gene copies (GC)/g (Calero-Cáceres et al., 2014). For the viruses in sludge, most studies have investigated nonenveloped enteroviruses, which are more difficult than enveloped viruses to inactivate in sewage sludge (Sano et al., 2003; Monpoeho et al., 2004; Jebri et al., 2014). Enteroviruses are also adopted as the virus indicator in the standard. While being used for land, the risk estimates, including those of adenoviruses and noroviruses, proved that the risk values of enteroviruses significantly underestimate the total infection risk of pathogenic microorganisms in sludge (Viau et al., 2011). By using a metagenomic sequencing method, 43 different types of human viruses, i.e., 26 DNA viruses and 17 RNA viruses, were detected in sewage sludge, and newly emerging viruses, such as coronavirus HKU1, the cosavirus, and the klassevirus, have high relative abundance, and the detection rate of coronavirus HKU1 exceeds $80 \%$ (Bibby and Peccia, 2013). The SARS-CoV2 virus that causes pneumonia is an enveloped virus (Foladori et al., 2020), and there is still limited knowledge about the inactivation efficiency of enveloped viruses in the treatment processes of sludge. A recent study showed that different temperatures of anaerobic digestion play an important role in the inactivation of the SARS-CoV-2 virus (Bardi and Oliaee, 2021). However, the high pathogenicity and rare data on its fate and transportation advocate concern for its ecological and health risks. In addition, the current virus enrichment methods are mainly for nonenveloped viruses, such as enteroviruses, and further studies must be done on the enrichment methods of enveloped viruses in sludge (Yang et al., 2020). The occurrence and risks of enveloped viruses in sludge treatment and reclamation should be carefully studied in the future.

Pathogenic protozoa that may be present in sludge include Giardia, Cryptosporidium, Entamoeba, Toxoplasma, and so on, and their infection may cause different symptoms, such as intermittent diarrhea, abdominal pain, cramps, bloody stools, weight loss, and dehydration (Amorós et al., 2016; Benito et al., 2020). Giardia and Cryptosporidium are often used as indicator protozoans in sewage. For parasitic worms, the inactivation rate of worm eggs is usually used as a biological indicator to evaluate sludge treatment performance, and worm egg concentrations are also used to assess the health risks of composted sludge to be applied to agricultural soil (Navarro et al., 2009; Amoah et al., 2018).

\section{Inactivation of pathogenic microorgan- isms by different sludge treatment processes}

\subsection{Composting and vermicomposting}

Sludge composting is a typical exothermic aerobic process and is one of the most widely used methods for sludge treatment (Liao et al., 2018). The efficiency of reducing the pathogenic load of sludge by composting is compared in Table 2 (Wéry et al., 2008). In the thermophilic phase, the composting temperature is in the range of $55^{\circ} \mathrm{C}$ to $70^{\circ} \mathrm{C}$, the majority of pathogenic microorganisms are inactivated, and sludge sanitation is achieved (Lung et al., 2001; Mehta et al., 2014). High temperature may cause enzyme denaturation, RNA inactivation, and protoplast membrane damage, and these effects lead to the death of microbial cells. Comparatively, hyperthermophilic composting may achieve a rapid rise in temperature to as high as $90^{\circ} \mathrm{C}$ within $24 \mathrm{~h}$, and a significantly higher capability to inactivate pathogenic microorganisms is expected compared to conventional composting (Liao et al., 2018). It was reported that $91 \%$ of resistance genes and $88 \%$ of mobile genetic elements were removed after 21 days of hyperthermophilic composting, and the ratios of conventional composting were observed to be $39 \%$ and $51 \%$, respectively (Liao et al., 2018). In addition, the interspecific competition of microorganisms was reported to play an important role in the inactivation of most 
(a)

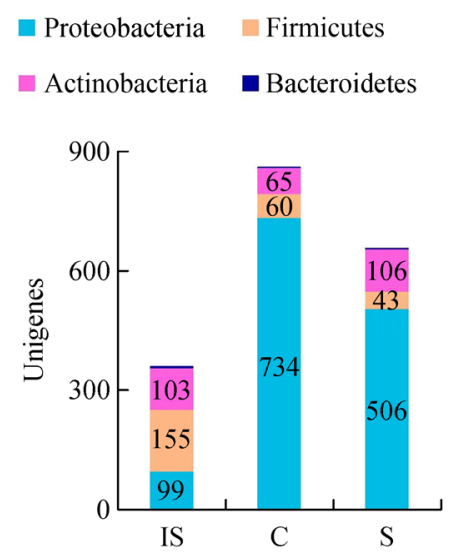

(b)

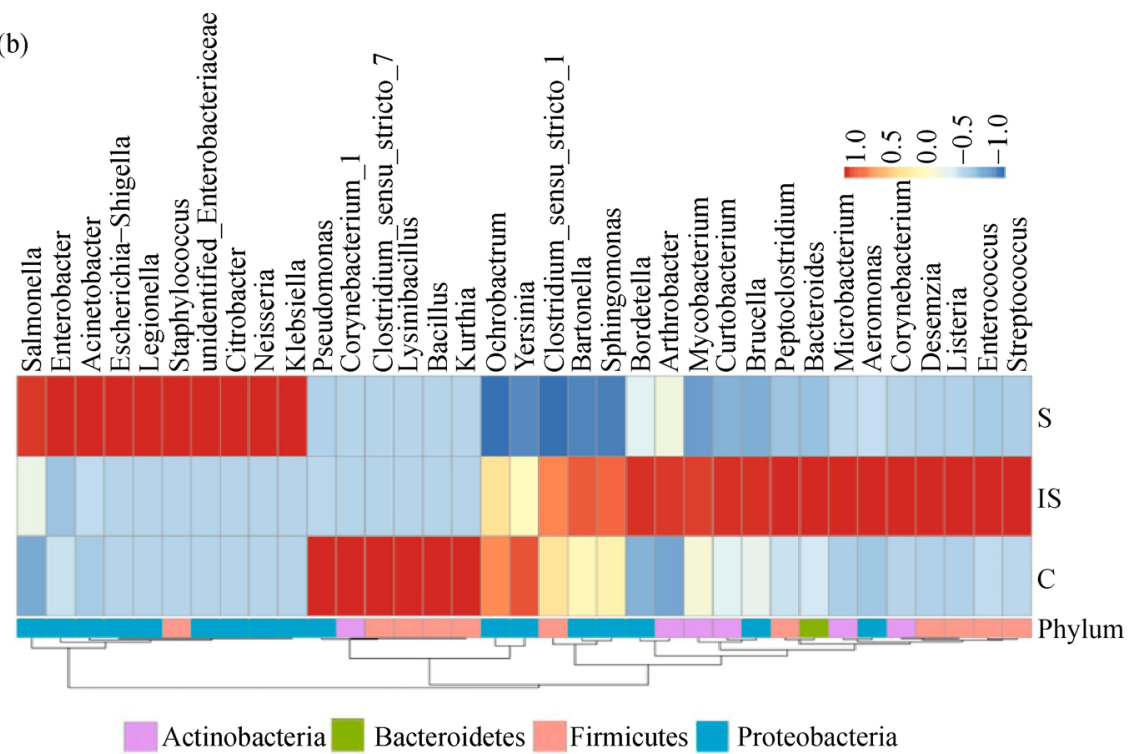

Fig. 2 Unigenes of human pathogenic bacteria at the phylum level (a) and their relative abundances $(\log 10$-transformed) at the genus level (b) in different samples obtained from initial sludge (IS), control (C), and sludge vermicompost (S). Reprinted with permission from Elsevier (Huang et al., 2020).

pathogenic microorganisms, and the rapid propagation of dominant bacteria inhibited the survival of pathogenic microorganisms accordingly (Millner et al., 1987; Pietronave et al., 2004). Dehydration can also lead to the rupture of the protein shell of viruses (Ward and Ashley, 1978). Further studies are required to illustrate the contribution of various factors, the optimized parameters, and the inactivation efficiency of different pathogenic microorganisms.

Conventional composting technology has disadvantages with regard to the removal of pathogenic microorganisms. For example, the presence of heat-resistant mutants greatly affects the inactivation of pathogens (Wichuk and Mccartney, 2007; Elving et al., 2010; Inglis et al., 2010), and this tends to increase the proportion of heat-resistant mutants in environments. Additionally, some specific bacteriophages or plant viruses, e.g., cucumber green mottle mosaic viruses, were reported to be highly resistant to conventional composting (Robledo-Mahón et al., 2019). At the end of thermophilic composting, the abundance of Pseudomonas spp. and Streptomyces spp. in sludge was detected to be near $1 \%$ of the entire community, which did induce the disease in crops such as potatoes (RobledoMahón et al., 2020).

In contrast to conventional composting, vermicomposting is a mesophilic process with a temperature below $35^{\circ} \mathrm{C}$, and this range enables the growth of worms and pathogenic microorganisms (Khwairakpam and Bhargava, 2009; Swati and Hait, 2018). Vermicomposting achieves sludge stabilization by the synergistic effect between worms and microbial populations (Table 2), and it has been reported that the enzyme activity and endosymbiotic microorganisms of earthworms play an important role (Monroy et al.,
2009; Sen and Chandra, 2009; Swati and Hait, 2018). Furthermore, the humate in sludge and gut transport of worms are also involved in pathogen inactivation (Soobhany et al., 2017). Comparatively, mesophilic vermicomposting was better than vermicomposting at controlling heat-resistant mutants, and the contrary result has also been reported before (Huang et al., 2020). The worm presentation significantly changed the community structure of pathogenic microorganisms, and their abundance was rarely reduced (Fig. 2). Most studies suggest that vermicomposting is reliable for inactivating pathogenic microorganisms in sludge, and there are still conflicts to be well illustrated.

\subsection{Anaerobic digestion and aerobic digestion}

Anaerobic digestion is one of the most popular techniques used to achieve sludge stabilization, and the inactivation efficiency of pathogenic microorganisms by different anaerobic digestion methods has been reported in various studies (Table 2). In general, the reduction in pathogenic load by thermophilic anaerobic digestion (TAD) was over $3 \log$ units, whereas that by mesophilic anaerobic digestion (MAD) was below 2 log units (Traub et al., 1986; Astals et al., 2012; Grübel and Suschka, 2015; Levantesi et al., 2015). The occurrence rates of human adenoviruses, enteroviruses, and human polyomaviruses in biosolids upon MAD were reported to be as high as $83 \%, 42 \%$, and $58 \%$, respectively (Wong et al., 2010). Conventional MAD can only meet the USEPA Class B biosolid standard with regard to pathogen control (USEPA, 1994; Lewis. and Gattie., 2002; Forster-Carneiro et al., 2010; Wong et al., 2010; Simmons and Xagoraraki, 2011) and can hardly 
achieve the Class A standard for agricultural purposes because it cannot ensure that the treated sludge is virtually pathogen-free. TAD improves the inactivation of pathogenic microorganisms to a greater extent; however, after $\mathrm{TAD}$, the detection of some pathogenic microorganisms has also been reported in many studies (Kearney et al., 1993; Astals et al., 2012; Levantesi et al., 2015). To achieve promising control of pathogenic microorganisms, the combination of conventional anaerobic digestion and other sanitation technologies, such as thermophilic pretreatment and sludge disinfection, may be practical to meet the Class A biosolid standard (Cheunbarn and Pagilla, 2000).

The mechanisms of pathogenic microorganism inactivation involved in anaerobic digestion are far from well illustrated, and the efficiency is highly dependent on different factors, such as temperature and solid retention time (Zhao and Liu, 2019). TAD at temperatures higher than $55^{\circ} \mathrm{C}$ is recognized to be efficient in obtaining Class A biosolids in the United States, and high temperature plays a determining role in the inactivation of pathogenic microorganisms (Kabrick and Jewell, 1982; Liu et al., 2011; Benito et al., 2020; López et al., 2020). A higher temperature improved inactivation, and TAD showed better performance than MAD to remove pathogenic microorganisms and ARGs (Diehl and LaPara, 2010; Pandey and Soupir, 2011; Rizzo et al., 2013; Forbis-Stokes et al., 2016). However, different pathogenic microorganism species have different tolerances to temperature (Watcharasukarn et al., 2009). Some pathogenic microorganisms, e.g., Bacillus cereus, L. monocytogenes, and some spores and eggs, exhibit strong resistance to temperature and can survive upon TAD treatment (Elmerdahl Olsen and Errebo Larsen, 1987; Kearney et al., 1993; Orzi et al., 2015; Zhao and Liu, 2019). Moreover, interspecific competition between pathogenic microorganisms and anaerobic bacteria also contributed to the lowered pathogenic load of sludge (Orzi et al., 2015). Additionally, the produced volatile fatty acids (VFAs) and free ammonia in anaerobic digestion also positively improved the inactivation of pathogenic microorganisms (Sahlström, 2003; Lloret et al., 2013; Fidjeland et al., 2015; Magri et al., 2015; Orzi et al., 2015). Free ammonia may penetrate the cell membrane and result in proton imbalance, potassium ion $\left(\mathrm{K}^{+}\right)$deficiency, and intracellular $\mathrm{pH}$ variation and adversely affect the normal physiologic function of cells (Rajagopal et al., 2013; Yenigün and Demirel, 2013; Chen et al., 2014).

Autothermal thermophilic aerobic digestion is reported to completely remove total coliforms of E. coli and Salmonella spp., and unfortunately, the removal efficiency of $C$. perfringens spores is as low as $1.97 \mathrm{log}$ units (Lloret et al., 2012). The elevated pH during aerobic digestion also showed inactivating effects toward pathogenic microorganisms (Kabrick and Jewell, 1982; Lloret et al., 2012). Additionally, two-phase anaerobic-aerobic digestion improved sludge digestion and methane production and positively favored sludge sanitation (Min Jang et al., 2019). Upon anaerobic digestion, thermophilic aerobic digestion further decreased the species of human bacterial pathogens from 44 to 16 , and the relative abundance of human bacterial pathogens was reduced from $2.42 \%$ to $0.77 \%$ (Fig. 3) (Min Jang et al., 2019).


Fig. 3 Species and relative abundance of human bacterial pathogens (HBPs) found in sludge treated by anaerobic digestion (AnD $\left.\mathrm{D}_{\text {residue }}\right)$ and thermophilic aerobic digestion $\left(\mathrm{TAD}_{\text {residue }}\right.$ ). Reprinted with permission from Elsevier (Min Jang et al., 2019). 


\subsection{Lime stabilization}

Convenient and cost-effective lime stabilization is widely used for sewage sludge sanitation and can significantly reduce the pathogenic load in sludge in USEPA guidelines (USEPA, 1994). Many studies have reported that after lime stabilization, pathogenic bacteria, indicator bacteria such as E. coli and Salmonella, and human viruses such as adenovirus and rotavirus can be reduced to below the detection limit (Table 2) (Gantzer et al., 2001; Plachá et al., 2008; Wong and Selvam, 2009; Yin et al., 2017; MartínDíaz et al., 2020). However, the risks of bacterial spores and helminth eggs with strong resistance to lime stabilization should also be considered (Capizzi-Banas et al., 2004). Bean et al. reported an insignificant difference in the numbers of Ascaris lumbricoides ova before and after lime stabilization (Bean et al., 2007). Lime stabilization can hardly inactivate nematode eggs in a short time, and the storage of sludge for over 6 months at $\mathrm{pH}>11.5$ may achieve this goal (Gantzer et al., 2001). For lime stabilization, other sanitation strategies should be introduced to strengthen pathogen inactivation.

In lime stabilization, the contributive effects on pathogen inactivation include high $\mathrm{pH}$, high temperature, dehydration, and ammonia toxicity, and extremely high $\mathrm{pH}$ is regarded to be the dominant factor (MignotteCadiergues et al., 2002; Capizzi-Banas et al., 2004). The addition of plentiful calcium oxide $(\mathrm{CaO})$ and calcium hydroxide $\left[\mathrm{Ca}(\mathrm{OH})_{2}\right]$ remarkably increased the sludge $\mathrm{pH}$ to as high as 12 and the sludge temperature to above $65^{\circ} \mathrm{C}$ (Pecson et al., 2007; Valderrama et al., 2013). Under strong alkaline conditions, the hydrolysis of nitrogen-containing organic matter led to increased concentrations of free ammonia, with toxic effects on microbial cells (Pecson et al., 2007; Magri et al., 2015). Additionally, CaO strongly absorbed water in sludge and gradually stabilized the physical and chemical properties by rapid water loss and inhibited microorganism survival. However, to achieve sludge stabilization and sanitation, extremely high lime doses and $\mathrm{pH}$ are both required, which adversely increase the inorganic contents and is detrimental to sludge disposal for land use and incineration.

\subsection{Heat drying}

Heat drying can greatly reduce the volume of sludge and improve the performance of sludge (Font et al., 2011; Deng et al., 2013). As the USEPA mentioned, sludge heating to over $80^{\circ} \mathrm{C}$ by hot gas may reduce the water content to below $10 \%$, which significantly reduces the pathogenic load and accordingly minimizes the negative effects (USEPA, 1994). However, the extent of pathogenic load reduction varies with the operating conditions (Gantzer et al., 2001; Mocé-Llivina et al., 2003; Monpoeho et al., 2004). Romdhana et al. compared four heat drying processes on hepatitis A virus control in sewage sludge; the agitated conductive process $\left(120^{\circ} \mathrm{C}\right)$, fry-drying process (vacuum, oil temperature: $95^{\circ} \mathrm{C}$ ) and drum drying process $\left(112^{\circ} \mathrm{C}-137^{\circ} \mathrm{C}\right)$ exhibited complete inactivation of hepatitis A virus within $20 \mathrm{~min}, 10 \mathrm{~min}$, and $10 \mathrm{~s}$, respectively, and solar drying showed a much lower efficiency (Romdhana et al., 2009). High temperature plays a determining role in the inactivation of pathogenic microorganisms (Romdhana et al., 2009; Naidoo et al., 2019; Espinosa et al., 2020; Gomes et al., 2020), and the efficiency is highly dependent on the heat transfer rate. Thin-layer drying with rapid heat transfer required much less time to achieve sludge drying and sanitation (Romdhana et al., 2009). The dehydration effect also greatly contributed to the inactivation of pathogenic microorganisms, and this was supported by the remarkable decrease in pathogenicity in air drying at natural temperature (Mondal et al., 2015; Kong et al., 2018).

\subsection{Innovative sludge treatment processes}

Recently, an increasing number of studies have proposed innovative processes such as microwave treatment, radiation, and chemical oxidation for sludge treatment and the control of pathogenic microorganisms.

\subsubsection{Microwave irradiation}

Microwave irradiation is often used as a pretreatment for anaerobic digestion because of the effective inactivation of pathogenic microorganisms (Hong et al., 2006; Coelho et al., 2011; Afolabi and Sohail, 2017; Mawioo et al., 2017; Gil et al., 2018). Microwaves showed the complete removal of E. coli, coliforms, Staphylococcus aureus, and Enterococcus faecalis, and the sludge volume was reduced by more than $60 \%$ due to the thermal effect of microwave radiation (Mawioo et al., 2017). Additionally, microwave pretreatment increased biogas production in anaerobic digestion by 35\% (Uma Rani et al., 2013).

The inactivation mechanism toward pathogenic microorganisms includes thermal effects as the dominant factor and electromagnetic radiation. In microwave radiation, elevated temperatures over $60^{\circ} \mathrm{C}$ effectively inactivate pathogenic microorganisms, and the efficiency is positively correlated with higher microwave energy (Mawioo et al., 2017). Microwave radiation also destroys the cell membrane, causes the exclusion of intracellular species (Cosgun and Semerci, 2019), and causes DNA damage to pathogenic microorganisms (Hong et al., 2004).

\subsubsection{High-energy electron beam radiation}

The radiation of $\gamma$-rays and high-energy electron beams $(\beta$ rays) is produced by an electron accelerator, and it was reported to reduce the sludge volume and improve sludge 
dissolution and organic pollutant degradation (Wang and Wang, 2007; Kim et al., 2011; Wu et al., 2017). Radiation is also effective in inactivating pathogens in sludge (Borrely et al., 1998; Chmielewski and Han, 2016). The pathogenic load may be promisingly reduced to a safe level at ray radiation doses above $2 \mathrm{kGy}$ (AL-Ghonaiem et al., 2010). Additionally, different microbial species have different sensitivities toward electron beam radiation. $\gamma$ ray radiation at a $1 \mathrm{kGy}$ dose contributed to the complete inactivation of $E$. coli in raw waste sludge, whereas the decrease ratio of the mold abundance was as low as $0.6 \mathrm{log}$ units (Ranković et al., 2020).

The inactivation of microorganisms by radiation is attributed to direct irradiation and indirect effects. In the irradiation of sewage sludge, radiation tends to destroy the structure of biological macromolecules such as nucleic acids and proteins and to cause ionization and destruction of intercellular substances (Wang and Wang, 2007; Chmielewski and Han, 2016). On the other hand, highenergy rays induce chemical processes such as sensitizer reactions and the generation of free radicals such as ${ }^{\bullet} \mathrm{OH}$, $\mathrm{e}_{\mathrm{aq}}{ }^{-}$, and $\mathrm{H}^{\bullet}$ (Wang and Wang, 2007; Chmielewski and Han, 2016). The formed radiation products may further interact with nucleic acids, proteins, and enzymes and hinder the normal physiologic process of cells.

\subsubsection{Electrochemical treatment}

Many studies have investigated the coagulation and disinfection effect of electrochemical treatment toward sewage and sludge (Huang et al., 2008; Cui et al., 2013; Lei et al., 2020), and the sanitation efficiency to produce Class A biosolids has been investigated recently (Navab Daneshmand et al., 2012; Rumky et al., 2020). In electrocoagulation, the in situ-produced coagulants reduce sewage turbidity by destabilization and flocculation effects, and most pathogens are captured and enter the sludge with flocs thereafter (Buzzini et al., 2007). Reactive oxygen and chlorine species were also produced during electrochemical treatment (Bakheet et al., 2020), which may destroy the microbial cell structure and inactivate the microorganisms in sludge (Fig. 4) (Zeng et al., 2019). At a voltage of $15 \mathrm{~V}$, the extent of the $E$. coli decrease was more than $3 \log$ units, and the extents of Salmonella spp. and Streptococcus faecalis decrease were nearly 5 log units. At an anode current density of $4.71 \mathrm{~A} / \mathrm{dm}^{2}$, the removal rate of E. coli and fecal coliform in municipal sewage sludge was reported to be as high as $5 \log$ units (Drogui et al., 2013). In addition, the combined use of a low-energy input electrochemical system and alkaline digestion may promisingly remove fecal coliform and $E$. coli in sewage



Fig. 4 (a) Images of microorganisms in sludge before and after electrochemical treatment at $8 \mathrm{~V}$ and $15 \mathrm{~V}$ and (b) distribution of the live and dead bacterial consortia observed with a confocal laser scanning microscope (CLSM). Reprinted with permission from Elsevier (Zeng et al., 2019). 
sludge and achieve the Biosolid Class A standard (Jafari and Botte, 2021).

To date, the inactivation mechanism of pathogenic microorganisms involved in the electrochemical process is far from well understood, and three positive effects were proposed (Navab Daneshmand et al., 2012; Yin et al., 2018; Zeng et al., 2019): 1) the generation of ohmic heat in electrochemical reactions; 2) the formation of different oxidants, such as free chlorine and reactive oxygen species; and 3) the extremely high or low $\mathrm{pH}$ at the interfaces of electrode plates. The quantitative contribution of these factors to sludge sanitization is not clear, and most studies suggest that ohmic heat is the primary contribution (Navab Daneshmand et al., 2012; Yin et al., 2018; Zeng et al., 2019). Future studies may focus on the other factors, and the molecular biological mechanisms involved in pathogen inactivation and the effects of electrochemical treatment on the post biological units for pathogen control.

\subsubsection{Chemical oxidation}

Strong oxidants with high redox potential tend to destroy the microorganism structure and degrade biological macromolecules such as enzymes and genetic materials, thus inactivating pathogenic microorganisms accordingly. Common oxidants include peracetic acid and chlorinecontaining disinfectants, e.g., $\mathrm{HOCl}$ and $\mathrm{Ca}(\mathrm{ClO})_{2}(\mathrm{Yu}$ et al., 2010; Yu et al., 2019d; Hu et al., 2021; Luukkonen et al., 2020). At peracetic acid doses over $480 \mathrm{mg} / \mathrm{L}$, the complete inactivation of $E$. coli and Salmonella spp. in sludge was observed (Luukkonen et al., 2020). $\mathrm{NaClO}$ at a dose of $2.2 \mathrm{~g} / \mathrm{L}$ decreased the most probable number of fecal coliform in sludge from $6.9 \log$ units to $0.8 \mathrm{log}$ units, and positive effects on improving dewatering and heavy metal leaching were also observed (Zhang et al., 2020). Higher doses of chemical oxidants are required to achieve the complete inactivation of pathogens in sludge than in sewage (Hu et al., 2021), owing to the protection of microbial cells and extracellular polymeric substances.

Advanced oxidation processes (AOPs) generate various free radicals, and recently, AOPs have been proposed to treat sewage and sludge. Fenton and Fenton-like processes have been indicated to effectively remove pathogenic microorganisms in sewage (Tong et al., 2020; Venieri et al., 2020; Wang et al., 2020). The persulfate at $0.5 \mathrm{mM}$ activated by solar energy may contribute to a $6.0 \log$ unit reduction in bacteria in sewage after $2 \mathrm{~h}$ of reaction (Ferreira et al., 2020). The combined use of ozone and zerovalent iron (ZVI) at doses of 30 and $63 \mathrm{mg} / \mathrm{g}$ TS may contribute to the reduction in the total coliforms and $E$. coli in sludge by $98.6 \%$ and $97.7 \%$, respectively, and ${ }^{\circ} \mathrm{OH}$ was reported to play an important role (Yu et al., 2019c). Wang et al. compared five pretreatment approaches for pathogen inactivation in sewage sludge, and electric-Fenton reactions exhibited the best performance and contributed to the removal of coliform and E. coli by $4.84 \log$ units and 3.86 $\log$ units after 60 min (Wang et al., 2021). Furthermore, $\mathrm{H}_{2} \mathrm{O}_{2}$ at a low dose can hardly improve the removal of pathogenic microorganisms in sludge due to its decomposition into water and oxygen instead of free radicals with its exposure to the organic matter in sludge (Yu et al., 2010). In addition to pathogen inactivation, AOPs were reported to improve sludge conditioning and dewatering performance (Maqbool et al., 2019; Yu et al., 2019d; Ge et al., 2020). The effects of AOPs on the degradation of micropollutants, the inactivation of ARGs, and sludge ecotoxicity in post land application should be further confirmed.

3.6 Comparison and summary of sludge treatment processes

The efficiency of reducing the pathogenic load of sludge by different sludge treatment processes is compared in Table 2. Lime stabilization is superior to conventional composting and mesophilic anaerobic digestion in inactivating pathogens, and several innovative sludge treatment processes can also reduce the pathogenic load in sludge to the sanitary level (Drogui et al., 2013; Mawioo et al., 2017; Luukkonen et al., 2020; Ranković et al., 2020). The reduction in the pathogenic load of sludge by conventional composting and anaerobic digestion obviously depends on the operating temperature (Liao et al., 2018; López et al., 2020 ), and the potential of thermophilic anaerobic digestion in the suppression and elimination of pathogens is significantly greater than that of mesophilic anaerobic digestion (Astals et al., 2012; Grübel and Suschka, 2015; Levantesi et al., 2015). However, the vast majority of sludge treatment processes are ineffective in controlling heat-resistant mutants, and the spores or ova of pathogens can also survive due to resistance to high temperatures and extreme $\mathrm{pH}$. Comparatively, vermicomposting is a more promising method to control their spread through sludge, but interaction mechanisms between worms, their endosymbiotic microorganisms and pathogens should be further studied from the perspective of microbial ecology. Furthermore, to more thoroughly inactivate pathogens in sludge and control the spread of heat-resistant mutants, a combination of two or more sludge treatment processes is recommended.

The mechanisms of pathogen inactivation by different sludge treatment processes are summarized in Table 3 . High temperature is the dominant factor for the inactivation of pathogens in most sludge treatment processes, and dehydration also plays an important role in the inactivation of pathogenic microorganisms. In innovative sludge treatment processes, some special pathogenic inactivation mechanisms, such as direct irradiation by a high-energy electron beam, have been reported (Wang and Wang, 2007; Chmielewski and Han, 2016). Different mechanisms may cause changes in the properties of sludge and affect the land application of sludge. Sludge after lime stabilization 
Table 2 Pathogenic load control by different sludge treatment processes

\begin{tabular}{|c|c|c|c|c|}
\hline Treatment & $\begin{array}{l}\text { Duration of the process; } \\
\text { maximum temperature }\end{array}$ & $\begin{array}{l}\text { Pathogenic microorganism or } \\
\text { microbial indicator }\end{array}$ & $\begin{array}{l}\text { Change in the } \\
\text { pathogenic load }\end{array}$ & Reference \\
\hline \multirow[t]{5}{*}{$\overline{\text { Composting }}$} & $\mathrm{NA}^{\mathrm{a}} ; \mathrm{NA}$ & Enteric viruses & $\mathrm{ND}^{\mathrm{b}}$ & Watanabe et al., 2002 \\
\hline & \multirow{4}{*}{$\begin{array}{l}4 \text { weeks of the active phase, } \\
\text { matured for } 2 \text { months and } \\
\text { stored for } 2-3 \text { months; } \\
60^{\circ} \mathrm{C}-70^{\circ} \mathrm{C}\end{array}$} & E. coli & ND & Wéry et al., 2008 \\
\hline & & C. perfringens & ND & Wéry et al., 2008 \\
\hline & & Salmonella spp. & ND & $\begin{array}{l}\text { Watanabe et al., } 2002 \text {; } \\
\text { Wéry et al., } 2008\end{array}$ \\
\hline & & Enterococcus spp. & $\downarrow\left(2.9 \log _{10} \text { gene copies/g }\right)^{\mathrm{c}}$ & Wéry et al., 2008 \\
\hline \multirow[t]{8}{*}{ Vermicomposting } & \multirow[t]{4}{*}{4 weeks; NA } & Fecal coliforms & $\downarrow\left(2.98 \log _{10} \mathrm{MPN} / \mathrm{g}\right)$ & Hait and Tare, 2011 \\
\hline & & Enterococcus & $\downarrow\left(2.21 \log _{10} \mathrm{MPN} / \mathrm{g}\right)$ & Hait and Tare, 2011 \\
\hline & & Salmonella & $\downarrow\left(1.82 \log _{10} \mathrm{MPN} / \mathrm{g}\right)$ & Hait and Tare, 2011 \\
\hline & & Helminths ova & ND & Hait and Tare, 2011 \\
\hline & \multirow[t]{4}{*}{40 days; NA } & Ochrobactrum anthropi & ND & Lv et al., 2018 \\
\hline & & Brevundimonas diminuta & ND & Lv et al., 2018 \\
\hline & & Eubacterium tenue & ND & Lv et al., 2018 \\
\hline & & Bacillus thuringiensis & ND & Lv et al., 2018 \\
\hline \multirow{5}{*}{$\begin{array}{l}\text { Mesophilic } \\
\text { anaerobic } \\
\text { digestion }\end{array}$} & $\mathrm{NA} ; 34.5^{\circ} \mathrm{C}$ & Bacteriophage $\mathrm{f} 2$ & $\downarrow\left(0.04 \log _{10}\right.$ PFU/Lper $\left.\mathrm{h}\right)$ & Traub et al., 1986 \\
\hline & 14 days; $36^{\circ} \mathrm{C}$ & Enterovirus & $\downarrow\left(1 \log _{10}\right.$ gene copies/g) & Monpoeho et al., 2004 \\
\hline & 20 days; $37^{\circ} \mathrm{C}$ & Somatic coliphages & $\downarrow\left(1 \log _{10}\right)$ & Astals et al., 2012 \\
\hline & & F-specific RNA-bacteriophages & $\downarrow\left(2.7 \log _{10}\right)$ & Astals et al., 2012 \\
\hline & & E. coli & $\downarrow\left(2.2 \log _{10}\right)$ & Astals et al., 2012 \\
\hline \multirow{3}{*}{$\begin{array}{l}\text { Thermophilic } \\
\text { anaerobic } \\
\text { digestion }\end{array}$} & \multirow[t]{3}{*}{15 days; $55^{\circ} \mathrm{C}$} & Somatic coliphages & $\downarrow\left(4.2 \log _{10}\right)$ & Astals et al., 2012 \\
\hline & & E. coli & $\downarrow\left(2.3 \log _{10}\right)$ & Astals et al., 2012 \\
\hline & & F-specific RNA-bacteriophages & $\downarrow\left(3.4 \log _{10}\right)$ & Astals et al., 2012 \\
\hline \multirow{6}{*}{$\begin{array}{l}\text { Aerobic } \\
\text { digestion }\end{array}$} & \multirow{3}{*}{$\begin{array}{l}30 \text { days; Winter: } 25^{\circ} \mathrm{C} \text {; } \\
\text { Other season: } 48^{\circ} \mathrm{C}\end{array}$} & E. coli & $\downarrow\left(3.5 \pm 0.9 \log _{10} \mathrm{MPN} / \mathrm{g}\right)$ & Gantzer et al., 2001 \\
\hline & & Enterococci & $\downarrow\left(2.1 \pm 0.5 \log _{10} \mathrm{MPN} / \mathrm{g}\right)$ & Gantzer et al., 2001 \\
\hline & & $\begin{array}{l}\text { Spores of sulfite-reducing } \\
\text { anaerobic bacteria }\end{array}$ & $\downarrow\left(1.3 \pm 0.5 \log _{10} \mathrm{MPN} / \mathrm{g}\right)$ & Gantzer et al., 2001 \\
\hline & \multirow[t]{3}{*}{14.6 days; $62^{\circ} \mathrm{C}$} & Total coliforms & ND & Lloret et al., 2012 \\
\hline & & Salmonella spp. & ND & $\begin{array}{l}\text { Liu et al., 2011; } \\
\text { Lloret et al., } 2012\end{array}$ \\
\hline & & C. perfringens spores & $\downarrow\left(1.97 \log _{10}\right.$ spores $\left./ \mathrm{mL}\right)$ & Lloret et al., 2012 \\
\hline \multirow{7}{*}{$\begin{array}{l}\text { Lime } \\
\text { stabilization }\end{array}$} & \multirow[t]{3}{*}{24 hours; NA } & Bacteriophage MS2 & ND & Hansen et al., 2007 \\
\hline & & Adenovirus type 5 & ND & $\begin{array}{l}\text { Bean et al., 2007; } \\
\text { Hansen et al., } 2007\end{array}$ \\
\hline & & Rotavirus & ND & $\begin{array}{l}\text { Bean et al., 2007; } \\
\text { Hansen et al., } 2007\end{array}$ \\
\hline & NA; NA & Enteroviruses & ND & Monpoeho et al., 2004 \\
\hline & \multirow[t]{3}{*}{24 hours; NA } & E. coli & $\downarrow\left(>6 \log _{10} \mathrm{MPN} / \mathrm{mL}\right)$ & $\begin{array}{l}\text { Bean et al., 2007; } \\
\text { Santos et al., } 2020\end{array}$ \\
\hline & & Salmonella & ND & Bean et al., 2007 \\
\hline & & Ascaris lumbricoides ova & No significant difference & Bean et al., 2007 \\
\hline \multirow{3}{*}{$\begin{array}{l}\text { Heat } \\
\text { drying }\end{array}$} & \multirow{3}{*}{$\begin{array}{l}\text { Indirect drying; } \\
10 \text { hours; } 108^{\circ} \mathrm{C}\end{array}$} & E. coli & $\downarrow\left(3.7 \pm 0.3 \log _{10} \mathrm{MPN} / \mathrm{g}\right)$ & Gantzer et al., 2001 \\
\hline & & Enterococci & $\downarrow\left(3.9 \pm 0.6 \log _{10} \mathrm{MPN} / \mathrm{g}\right)$ & Gantzer et al., 2001 \\
\hline & & $\begin{array}{l}\text { Spores of sulfite-reducing } \\
\text { anaerobic bacteria }\end{array}$ & $\downarrow\left(3.2 \pm 0.1 \log _{10} \mathrm{MPN} / \mathrm{g}\right)$ & Gantzer et al., 2001 \\
\hline
\end{tabular}




\begin{tabular}{|c|c|c|c|c|}
\hline Treatment & $\begin{array}{l}\text { Duration of the process; } \\
\text { maximum temperature }\end{array}$ & $\begin{array}{l}\text { Pathogenic microorganism or } \\
\text { microbial indicator }\end{array}$ & $\begin{array}{l}\text { Change in the } \\
\text { pathogenic load }\end{array}$ & Reference \\
\hline \multirow{4}{*}{$\begin{array}{l}\text { Microwave } \\
\text { technology }\end{array}$} & \multirow[t]{4}{*}{ MW energy: $3.4 \mathrm{kWh}$} & E. coli & ND & Mawioo et al., 2017 \\
\hline & & Coliforms & ND & Mawioo et al., 2017 \\
\hline & & S. aureus & ND & Mawioo et al., 2017 \\
\hline & & E. faecalis & ND & Mawioo et al., 2017 \\
\hline \multirow[t]{3}{*}{$\begin{array}{l}\text { Electrochemical } \\
\text { pretreatment }\end{array}$} & \multirow[t]{3}{*}{$\begin{array}{l}\text { Applied voltage: } 15 \mathrm{~V} \text {; } \\
\text { Time: } 1 \text { hour }\end{array}$} & E. coli & $\begin{array}{l}\downarrow \\
\left(3.12 \pm 0.2 \log _{10} \text { CFU/g TS }\right)\end{array}$ & Zeng et al., 2019 \\
\hline & & Salmonella spp. & $\downarrow\left(>4 \log _{10}\right.$ CFU/g TS $)$ & Zeng et al., 2019 \\
\hline & & S. faecalis & $\downarrow\left(>4 \log _{10}\right.$ CFU/g TS $)$ & Zeng et al., 2019 \\
\hline \multirow[t]{2}{*}{ Gamma radiation } & \multirow[t]{2}{*}{$\begin{array}{l}\text { Dose of gamma irradiation: } \\
2 \mathrm{kGy}\end{array}$} & Fecal coliforms & ND & $\begin{array}{l}\text { AL-Ghonaiem et al., } \\
2010\end{array}$ \\
\hline & & Salmonella spp. & ND & $\begin{array}{l}\text { AL-Ghonaiem et al., } \\
2010\end{array}$ \\
\hline \multirow[t]{2}{*}{$\begin{array}{l}\text { Peracetic acid } \\
\text { (PAA) oxidation }\end{array}$} & \multirow[t]{2}{*}{$\begin{array}{l}480 \mathrm{mg} \text { of } 100 \% \text { PAA } \\
\text { per L of sludge }\end{array}$} & E. coli & ND & $\begin{array}{l}\text { Luukkonen et al., } \\
2020\end{array}$ \\
\hline & & Salmonella spp. & ND & $\begin{array}{l}\text { Luukkonen et al., } \\
2020\end{array}$ \\
\hline
\end{tabular}

Note: a) Not available; b) Not detected; c) Signifies the decrease in pathogenic load with the log value of the decrease in brackets.

Table 3 Mechanisms of pathogen inactivation by different sludge treatment processes

\begin{tabular}{|c|c|c|}
\hline Treatment & Mechanisms & Reference \\
\hline \multirow[t]{3}{*}{ Composting } & High temperature in the thermophilic phase & Mehta et al., 2014; Liao et al., 2018 \\
\hline & Interspecific competition of microorganisms & Pietronave et al., 2004 \\
\hline & Dehydration & Ward and Ashley, 1978 \\
\hline \multirow[t]{2}{*}{ Vermicomposting } & $\begin{array}{l}\text { Enzyme activity and endosymbiotic microorganisms } \\
\text { of earthworms }\end{array}$ & Monroy et al., 2009; Swati and Hait, 2018 \\
\hline & Humate in sludge and gut transport of worms & Soobhany et al., 2017 \\
\hline \multirow{4}{*}{$\begin{array}{l}\text { Anaerobic digestion and } \\
\text { aerobic digestion }\end{array}$} & High temperature & López et al., 2020 \\
\hline & Elevated $\mathrm{pH}$ & Kabrick and Jewell, 1982; Lloret et al., 2012 \\
\hline & $\begin{array}{l}\text { Interspecific competition between pathogens and } \\
\text { anaerobic bacteria }\end{array}$ & Orzi et al., 2015 \\
\hline & Produced VFAs and free ammonia & $\begin{array}{l}\text { Sahlström, 2003; Lloret et al., 2013; } \\
\text { Fidjeland et al., 2015; Magri et al., } 2015\end{array}$ \\
\hline \multirow[t]{4}{*}{ Lime stabilization } & Extremely high $\mathrm{pH}$ & Pecson et al., 2007; Valderrama et al., 2013 \\
\hline & High temperature & Pecson et al., 2007; Valderrama et al., 2013 \\
\hline & Dehydration & Capizzi-Banas et al., 2004 \\
\hline & Ammonia toxicity & Capizzi-Banas et al., 2004 \\
\hline \multirow[t]{2}{*}{ Heat drying } & High temperature & Naidoo et al., 2019; Gomes et al., 2020 \\
\hline & Dehydration & Mondal et al., 2015; Kong et al., 2018 \\
\hline \multirow[t]{3}{*}{ Microwave technology } & Thermal effect & Mawioo et al., 2017 \\
\hline & $\begin{array}{l}\text { Cell membrane destruction and the exclusion of } \\
\text { intracellular species }\end{array}$ & Cosgun and Semerci, 2019 \\
\hline & DNA damage & Hong et al., 2004 \\
\hline \multirow[t]{2}{*}{$\begin{array}{l}\text { High-energy electron } \\
\text { beam radiation }\end{array}$} & $\begin{array}{l}\text { Direct irradiation (inactivation of biomacromolecules } \\
\text { and the ionization and destruction of the intercellular } \\
\text { substance) }\end{array}$ & $\begin{array}{l}\text { Wang and Wang, 2007; } \\
\text { Chmielewski and Han, } 2016\end{array}$ \\
\hline & $\begin{array}{l}\text { Indirect effects (sensitizer reaction and the generation } \\
\text { of free radical) }\end{array}$ & $\begin{array}{l}\text { Wang and Wang, 2007; } \\
\text { Chmielewski and Han, } 2016\end{array}$ \\
\hline
\end{tabular}




\begin{tabular}{lll}
\hline Treatment & Mechanisms & Reference \\
\hline $\begin{array}{l}\text { Electrochemical } \\
\text { pretreatment }\end{array}$ & Generation of ohmic heat in electrochemical reactions & Navab Daneshmand et al., 2012; \\
& Yin et al., 2018; Zeng et al., 2019 \\
& $\begin{array}{l}\text { Formation of different oxidants such as free chlorine } \\
\text { and reactive oxygen species }\end{array}$ & Navab Daneshmand et al., 2012; \\
& $\begin{array}{l}\text { Extremely high or low pH at the interfaces of electrode } \\
\text { plates }\end{array}$ & Yin et al., 2018; Zeng et al., 2019 \\
& $\begin{array}{l}\text { Destruction of the microorganism structure and degradation } \\
\text { of biomacromolecules }\end{array}$ & Yin et al., 2018; Zeng et al., 2019 \\
Chemical oxidation & Hu et al., 2020; Luukkonen et al., 2020 \\
\hline
\end{tabular}

has an extremely high $\mathrm{pH}$ (Mosquera-Losada et al., 2012). Oxidants can change the oxidation-reduction potential of sludge. Microwave irradiation or high-energy electron beam radiation may induce mutated genes (Sado et al., 2001; Sutherland et al., 2010). These are not conducive to the subsequent land application of sludge. Moreover, due to the input of energy or the addition of a large amount of oxidant, innovative sludge treatment processes may be expensive with regard to the cost of implementation and operation, and the cost estimation of innovative sludge treatment processes, especially microwave irradiation and high-energy electron beam radiation (Zimek, 2020), should be further studied. Comparatively, composting, anaerobic digestion and lime stabilization are more costeffective, biofuels such as $\mathrm{CH}_{4}$ can be produced by anaerobic digestion, and mature and sanitary compost can be an effective soil conditioner.

\section{Pathogen risk in sludge treatment and land application}

\subsection{Pathogen risk during sludge treatment}

Sludge treatment involves concentration, conditioning, dehydration, transportation and other links, and includes aerobic and anaerobic digestion, composting, heat treatment, and other processes (Kelessidis and Stasinakis, 2012; Yang et al., 2015; Zhang et al., 2016; Yu et al., 2017; Wang et al., 2019; Yu et al., 2019a). The exposure of pathogenic microorganisms via contact and air inhalation in these processes should be evaluated and minimized as much as possible for the operators (Viau and Peccia, 2009; Han et al., 2021). In the process of sludge treatment, the exposure and health risk via bioaerosols should be well considered. The colony-counting method was proposed to detect bioaerosols, and the aerosol levels in the sludge thickening house were observed to be the highest at a fungal concentration of $8775 \pm 406 \mathrm{CFU} / \mathrm{m}^{3}$, which was remarkably higher than the acceptable guideline of $500 \mathrm{CFU} / \mathrm{m}^{3}$ (Xu et al., 2020). In the areas near the sludge thickening basin, the contents of culturable bacterial aerosols and fungal aerosols were also the highest at $1697 \mathrm{CFU} / \mathrm{m}^{3}$ and $930 \mathrm{CFU} / \mathrm{m}^{3}$, respectively (Li et al., 2016a). Aerosols containing $S$. aureus may be used as an indicator of health risk. In residual sludge storage yards, the particle size of $S$. aureus bioaerosols was observed to be in the range of 3.3 to $4.7 \mathrm{~mm}$, and the contents of respirable bioaerosols $<4.7 \mathrm{~mm}$ in size were also higher than those in aeration tanks (Yan et al., 2021). Arcobacter was observed to be the dominant taxon in aerosols, and the pathogens in indoor bioaerosols mainly came from sewage and sludge (Yang et al., 2019). Although a study showed that ARGs in liquid sludge from aeration tanks could diffuse through aerosols (Gaviria-Figueroa et al., 2019), there is still a lack of evidence suggesting that ARGs can diffuse through bioaerosols during sludge treatment.

In addition, there is also the risk of pathogens spreading in the process of sludge stabilization. The higher risk of bioaerosol exposure in sludge treatment units may be due to external forces such as dehydration applied to sludge (Xu et al., 2020). An aerosolization experiment using sludge of anaerobic digesters showed that some opportunistic pathogens were more likely to be aerosolized (Moletta-Denat et al., 2010), so attention should be given to the risk of pathogenic microorganisms that may exist in the biogas produced by the anaerobic digestion of sludge. It has been proven that long-term occupational exposure to bioaerosols in composting sites can adversely affect health (Schlosser et al., 2009). A recent study on bioaerosols found that Fusarium graminerum and Stenotrophomonas rhizophila had high bioaerosolization indexes during sludge biostabilization, which might cause risks to human health ( $\mathrm{Lu}$ et al., 2021). In addition, inhalable dust could also be used as an indicator of culturable bacterial concentrations in the air during sludge composting (Schlosser et al., 2018). Although many studies have focused on the exposure risk of bioaerosols in sludge treatment units, there is still a lack of comprehensive data to assess the transmission and exposure pathways and health risks of pathogenic microorganisms. Additionally, the characterization and assessment of health risk by nonindicative pathogenic microorganisms should also be considered. 
4.2 Pathogen risk associated with the land application of sludge

The ecological and health risks involved in the post application of sludge should be carefully evaluated. Currently, sludge landfills are prohibited in an increasing number of cities, and many WWTPs are planning to upgrade sludge treatment facilities to harvest the resources and energy in sludge. Land application has been widely implemented for global sludge reclamation and disposal. Sludge has been widely used as fertilizer on land after composting (Major et al., 2020). The process of concentration, anaerobic digestion, dehydration, and land application is considered to be one of the priority technical routes in China (Yang et al., 2015). The risks of different pathogen infections toward plants, animals and humans involved in land application have received great concern. While introducing undisinfected sludge on land, the desorption and leaching of adsorbed viruses may occur and potentially pollute water sources (Chetochine et al., 2006). Additionally, the risks of pathogenic aerosol inhalation occur while putting sludge into containers, spraying sludge, and mixing the soil (Brooks et al., 2005; Paez-Rubio et al., 2007). Brooks et al. used coliphage MS2 as an indicator virus and reported the low risks of onetime and annual infection by inhaling sludge aerosols at a downwind distance above $30.5 \mathrm{~m}$ (Brooks et al., 2005). Unfortunately, there is still much uncertainty due to insufficient information on pathogen species and concentrations, exposure pathways, and corresponding doseresponse effects. In terms of the risk of different exposure routes, direct ingestion is generally considered greater than aerosol transmission, indirectly contaminating groundwater and plants (Brooks et al., 2012). However, the possibility of people directly ingesting contaminated soil is low, so bioaerosols are considered the most concerning exposure risk related to the land application of sludge (Tanner et al., 2008; Viau et al., 2011).

In addition, the ingestion of agricultural crops using sludge as fertilizer sources and soil conditioners may still have pathogen infection risks. The risk of infection by worm eggs is relatively high while eating lettuce grown on sludge-improved soil. It may take as long as 30 to 40 days to reduce this risk to the WHO tolerable risk value of $10^{-4}$ (Amoah et al., 2018). The application of sewage sludge on land increased the exposure risk of root crops to Cryptosporidium oocysts and Salmonellas by counts of 0.033 and $0.070 \mathrm{~kg}^{-1}$, respectively (Gale, 2003). However, the infection risk encountered by eating vegetables on soil treated with sludge application was reported to be low based on the intake of $283.7 \mathrm{~g}$ of vegetables per person per day (Gale, 2005). Biosolids upon anaerobic digestion and aerobic digestion were used for farmland, and ARGs were observed by qPCR and high-throughput sequencing analysis to rarely transfer to vegetables during harvest (Lau et al., 2017). Comparatively, the use of raw and anaerobically digested sludge may greatly increase the ARG abundance in harvested vegetables compared to land without sludge application, and this phenomenon disappears after one year of application (Rahube et al., 2014). Therefore, the spreading risk of pathogens and ARGs from sludge to crops and vegetables may be affected by many factors, such as the sludge treatment processes, the amount of applied sludge, and the time intervals between sludge application and harvesting.

As mentioned in the USEPA 503 regulation, Class A biosolids must be virtually pathogen-free, whereas Class B biosolids may contain pathogens (Iranpour and Cox, 2007). When Class B biosolids are applied to land, the risk to public health and the environment may be minimized if the guidelines to reduce exposure are followed, e.g., restricting site entry and reducing vector attractants (USEPA, 1994). However, the standards for Class A biosolids only include the detection of fecal coliform and Salmonella, so Class A biosolids may have other risks in considering the various pathogens and the large number of unknown microorganism species in sludge. It was reported that by measuring the concentrations of fecal coliform indicators, pathogen-free Class A biosolids can hardly be confirmed, and fecal coliform inactivation is insufficient to assure safe pathogen inactivation (Viau et al., 2011). In addition, the regrowth of pathogenic microorganisms in treated biosolids tended to occur in the case of improper storage (Sidhu et al., 2001; Zaleski et al., 2005). After being treated by thermophilic anaerobic digestion, the density of fecal coliforms in biosolids may meet the Class A biosolid requirement. However, the density may unfortunately increase to as high as $10^{7} \mathrm{MPN} / \mathrm{g}$ dry weight after the application of biosolids to farmland, which indicates the regrowth of fecal coliforms during transportation (Iranpour and Cox, 2006). Upon the application of biosolids to land, the regrowth of Salmonella was observed to be on the time scale of 10 to 39 weeks, whereas that of E. coli was between 19 and 25 weeks (Eamens et al., 2006). However, the regrowth potential of different pathogen species has not been carefully evaluated, and the quantitative standard to rediscover these pathogens and assess their risks may be of crucial importance.

\subsection{Potential application of quantitative microbial risk assessment in sludge}

To achieve a reliable evaluation of risks, a better understanding of the migration, transmission, exposure and regrowth of pathogens in sludge treatment and biosolid land application is valuable. Quantitative microbial risk assessment (QMRA) has been widely employed to assess health risks in different environments and the safety of food (Lammerding, 2006; Elliott et al., 2019; Chen et al., 2021), and the development of standard methods such as QMRA is expected to improve the reliability of risk 
assessments on sludge land applications. QMRA by mathematical methods may quantitatively evaluate the probability of infection, disease, and death caused by pathogenic microorganisms and integrates information on the occurrence, infection, exposure assessment, and doseresponse model of pathogens (Eisenberg et al., 2008; Hamilton and Haas, 2016). QMRA has been applied to assess the risk of SARS-CoV-2 in WWTPs in South Brazil; the viable virus concentrations were determined to be in the range from 0.04 to $5.23 \mathrm{PFU} \cdot \mathrm{mL}^{-1}$ at the WWTP entrance, and the risk in aggressive and extreme situations was higher than the tolerable value (Zaneti et al., 2021). QMRA has also been applied to assess the aerosol exposure risk in different units of WWTPs, including sludge treatment units; the hazard index of exposure was higher than 1, and L. pneumophila exhibited a higher risk of infection and disease in men than in women (Xu et al., 2020). This may be ascribed to the higher exposure dose considering that men have a higher average respiratory volume (Yan et al., 2021). Regarding the exposure risk of $S$. aureus aerosols, staff at sludge storage yards have higher risks than field engineers (Yan et al., 2021). QMRA may also be applied to assess the exposure risk involved in the land application of sludge. After applying Class B biosolids to land, enteroviruses and Campylobacter jejuni caused the greatest risk in a short time among these pathogenic microorganisms, and the direct consumption of soil was the greatest one-time risk, with a value above $10^{-1}$ (Brooks et al., 2012). In addition, the exposure risk of viruses was mainly derived from biosolids, and the land application of biosolids showed a higher risk than manure due to the high infectiousness of viruses (Tanner et al., 2008; Brooks et al., 2012).

However, most risk studies of sludge treatment and disposal processes only focused on one or a few pathogenic microorganisms, and the representativeness of the pathogenic microorganisms used requires further verification (Yang et al., 2019; Xu et al., 2020; Yan et al., 2021). Selecting more pathogenic microorganisms with a wide distribution, high abundance and high toxicity is recommended for risk assessment after a more comprehensive test of sludge and environmental samples is performed. Because the values of the parameters in the model vary with pathogenic microorganisms (Armstrong and Haas, 2007; Van Abel et al., 2017; Hamilton et al., 2019), the dose-response model is very important for newly discovered pathogenic microorganisms. For highrisk pathogens without regulations and standards in sludge, the corresponding dose-response model needs more research to increase the reliability of risk assessment. When analyzing exposure pathways, all the possibilities of the three media, solid, liquid and gas, as well as the influence of the regeneration of pathogenic microorganisms at different time nodes, should be fully considered (Eisenberg et al., 2008). To control the exposure of pathogens in sludge, a hazard analysis and critical control point (HACCP) system can be adopted to control exposure risks at key points (Tsitsifli and Tsoukalas, 2021). More representative pathogens, more comprehensive exposure pathways and more accurate dose-response models can make risk assessments during sludge treatment and disposal more reliable.

\section{Conclusions and perspectives}

The risk control of pathogenic microorganisms in sludge is crucially important to achieve resource and energy recovery, minimize adverse environmental effects, and ensure public health safety. This review clarifies the diversity and detection methods of pathogenic microorganisms in sludge, including pathogenic bacteria, viruses, and protozoans. The control performance and inactivation mechanism of various sludge treatment processes on pathogenic microorganisms are analyzed and compared with emphasis. And the health risks involved in sludge treatment and land application are discussed. These results may be valuable for pathogen risk control with regard to sludge management.

Unfortunately, there is still a lack of sufficient research on the detection methods, occurrence, survival, transfer, and infection of unconventional pathogens in sludge, such as some nonenveloped viruses, which restricts us from proposing an effective strategy to avoid infection in this pandemic period. The control performance of different sludge treatment processes on pathogens can provide us with some references. Although most sludge treatment processes can inactivate indicator pathogens through different mechanisms, such as high temperature, extreme $\mathrm{pH}$, and competition of microorganisms, combined treatment processes are still suggested as a strategy to enhance control performance. Finally, it is important to update the guidelines and standards to regulate the treatment and disposal of sludge based on fundamental research, field investigation and theoretical modeling. For a more comprehensive and reliable quantitative assessment model, it is important to combine diverse species and concentrations of pathogens, exposure pathways, and dose-response data in the future.

Acknowledgements This study was sponsored by the National Natural Science Foundation of China (Grant Nos. 51925807 and 52091542) and the Excellent Innovation Project of Research Center for Eco-Environmental Sciences (CAS RCEES-EEI-2019-02).

\section{References}

Afolabi O O D, Sohail M (2017). Microwaving human faecal sludge as a viable sanitation technology option for treatment and value recovery: A critical review. Journal of Environmental Management, 187: 401415

AL-Ghonaiem M I, Ibrahim A S S, Al-Salamah A A (2010). Application 
of gamma irradiation in treatment of waste activated sludge to obtain class a biosolids. American Journal of Environmental Sciences, 6(6): 500-504

Amoah I D, Reddy P, Seidu R, Stenström T A (2018). Concentration of soil-transmitted helminth eggs in sludge from South Africa and Senegal: A probabilistic estimation of infection risks associated with agricultural application. Journal of Environmental Management, 206: 1020-1027

Amorós I, Moreno Y, Reyes M, Moreno-Mesonero L, Alonso J L (2016). Prevalence of Cryptosporidium oocysts and Giardia cysts in raw and treated sewage sludges. Environmental Technology, 37(22): 2898-2904

Armstrong T W, Haas C N (2007). A quantitative microbial risk assessment model for Legionnaires' disease: Animal model selection and dose-response modeling. Risk Analysis: An Official Publication of the Society for Risk Analysis, 27(6): 1581-1596

Astals S, Venegas C, Peces M, Jofre J, Lucena F, Mata-Alvarez J (2012). Balancing hygienization and anaerobic digestion of raw sewage sludge. Water Research, 46(19): 6218-6227

Bakheet B, Prodanovic V, Deletic A, McCarthy D (2020). Effective treatment of greywater via green wall biofiltration and electrochemical disinfection. Water Research, 185: 116228

Balboa S, Mauricio-Iglesias M, Rodriguez S, Martínez-Lamas L, Vasallo F J, Regueiro B, Lema J M (2021). The fate of SARS-COV-2 in WWTPS points out the sludge line as a suitable spot for detection of COVID-19. Science of the Total Environment, 772: 145268

Bardi M J, Oliaee M A (2021). Impacts of different operational temperatures and organic loads in anaerobic co-digestion of food waste and sewage sludge on the fate of SARS-CoV-2. Process Safety and Environmental Protection, 146: 464-472

Bean C L, Hansen J J, Margolin A B, Balkin H, Batzer G, Widmer G (2007). Class $B$ alkaline stabilization to achieve pathogen inactivation. International Journal of Environmental Research and Public Health, 4(1): 53-60

Benito M, Menacho C, Chueca P, Ormad M P, Goñi P (2020). Seeking the reuse of effluents and sludge from conventional wastewater treatment plants: Analysis of the presence of intestinal protozoa and nematode eggs. Journal of Environmental Management, 261: 110268

Bibby K, Peccia J (2013). Identification of viral pathogen diversity in sewage sludge by metagenome analysis. Environmental Science \& Technology, 47(4): 1945-1951

Boehm A B, Graham K E, Jennings W C (2018). Can we swim yet? Systematic review, meta-analysis, and risk assessment of aging sewage in surface waters. Environmental Science \& Technology, 52 (17): 9634-9645

Borrely S I, Cruz A C, Del Mastro N L, Sampa M H O, Somessari E S (1998). Radiation processing of sewage and sludge: A review. Progress in Nuclear Energy, 33(1-2): 3-21

Brooks J P, McLaughlin M R, Gerba C P, Pepper I L (2012). Land application of manure and Class B biosolids: An occupational and public quantitative microbial risk assessment. Journal of Environmental Quality, 41(6): 2009-2023

Brooks J P, Tanner B D, Gerba C P, Haas C N, Pepper I L (2005). Estimation of bioaerosol risk of infection to residents adjacent to a land applied biosolids site using an empirically derived transport model. Journal of Applied Microbiology, 98(2): 397-405
Buzzini A P, Patrizzi L J, Motheo A J, Pires E C (2007). Preliminary evaluation of the electrochemical and chemical coagulation processes in the post-treatment of effluent from an upflow anaerobic sludge blanket (UASB) reactor. Journal of Environmental Management, 85 (4): $847-857$

Cai L, Zhang T (2013). Detecting human bacterial pathogens in wastewater treatment plants by a high-throughput shotgun sequencing technique. Environmental Science \& Technology, 47(10): 54335441

Calero-Cáceres W, Melgarejo A, Colomer-Lluch M, Stoll C, Lucena F, Jofre J, Muniesa M (2014). Sludge as a potential important source of antibiotic resistance genes in both the bacterial and bacteriophage fractions. Environmental Science \& Technology, 48(13): 7602-7611

Capizzi-Banas S, Deloge M, Remy M, Schwartzbrod J (2004). Liming as an advanced treatment for sludge sanitisation: Helminth eggs elimination: Ascaris eggs as model. Water Research, 38(14-15): 3251-3258

Carraturo F, Del Giudice C, Morelli M, Cerullo V, Libralato G, Galdiero E, Guida M (2020). Persistence of SARS-CoV-2 in the environment and COVID-19 transmission risk from environmental matrices and surfaces. Environmental Pollution, 265(Pt B): 115010

Chen J L, Ortiz R, Steele T W J, Stuckey D C (2014). Toxicants inhibiting anaerobic digestion: A review. Biotechnology Advances, 32(8): 1523-1534

Chen Y H, Yan C, Yang Y F, Ma J X (2021). Quantitative microbial risk assessment and sensitivity analysis for workers exposed to pathogenic bacterial bioaerosols under various aeration modes in two wastewater treatment plants. Science of the Total Environment, 755(Pt 2): 142615

Chetochine A S, Brusseau M L, Gerba C P, Pepper I L (2006). Leaching of phage from Class B biosolids and potential transport through soil. Applied and Environmental Microbiology, 72(1): 665-671

Cheunbarn T, Pagilla K R (2000). Anaerobic thermophilic/mesophilic dual-stage sludge treatment. Journal of Environmental Engineering, 126(9): 796-801

Chmielewski A G, Han B (2016). Electron Beam Technology for Environmental Pollution Control. Topics in Current Chemistry (Cham), 374(5): 68

Claesson M J, Wang Q, O'Sullivan O, Greene-Diniz R, Cole J R, Ross R P, O'Toole P W (2010). Comparison of two next-generation sequencing technologies for resolving highly complex microbiota composition using tandem variable $16 \mathrm{~S}$ rRNA gene regions. Nucleic Acids Research, 38(22): e200

Coelho N M G, Droste R L, Kennedy K J (2011). Evaluation of continuous mesophilic, thermophilic and temperature phased anaerobic digestion of microwaved activated sludge. Water Research, 45 (9): 2822-2834

Cosgun S, Semerci N (2019). Combined and individual applications of ozonation and microwave treatment for waste activated sludge solubilization and nutrient release. Journal of Environmental Management, 241: 76-83

Cui X, Quicksall A N, Blake A B, Talley J W (2013). Electrochemical disinfection of Escherichia coli in the presence and absence of primary sludge particulates. Water Research, 47(13): 4383-4390

Dai X, Li X, Yang W, Dai L, Dong B (2020). Virus in sewage sludge from wastewater treatment plant: Occurrence and potential risk 
during sludge treatment and disposal. Water \& Wastewater Engineering, 46(3): 60-73 (in Chinese)

Dauknys R, Mažeikienè A, Paliulis D (2020). Effect of ultrasound and high voltage disintegration on sludge digestion process. Journal of Environmental Management, 270: 110833

Deng W, Su Y, Yu W (2013). Theoretical calculation of heat transfer coefficient when sludge drying in a nara-type paddle dryer using different heat carriers. Procedia Environmental Sciences, 18: 709715

Diehl D L, LaPara T M (2010). Effect of temperature on the fate of genes encoding tetracycline resistance and the integrase of class 1 integrons within anaerobic and aerobic digesters treating municipal wastewater solids. Environmental Science \& Technology, 44(23): 9128-9133

Drogui P, Bureau M A, Mercier G, Blais J F (2013). Effectiveness of electrooxidation process for stabilizing and conditioning of urban and industrial wastewater sludge. Water Environment Research: A Research Publication of the Water Environment Federation, 85(1): $35-43$

Eamens G J, Waldron A M, Nicholls P J (2006). Survival of pathogenic and indicator bacteria in biosolids applied to agricultural land. Australian Journal of Soil Research, 44(7): 647-659

Eisenberg J N S, Moore K, Soller J A, Eisenberg D, Colford J M Jr (2008). Microbial risk assessment framework for exposure to amended sludge projects. Environmental Health Perspectives, 116 (6): 727-733

Elliott J G, Taylor-Edmonds L, Andrews R C (2019). Quantitative microbial risk assessments for drinking water facilities: Evaluation of a range of treatment strategies. Environmental Science. Water Research \& Technology, 5(11): 1943-1955

Elmerdahl Olsen J, Errebo Larsen H (1987). Bacterial decimation times in anaerobic digestions of animal slurries. Biological Wastes, 21(3): $153-168$

Elving J, Ottoson J R, Vinnerås B, Albihn A (2010). Growth potential of faecal bacteria in simulated psychrophilic/mesophilic zones during composting of organic waste. Journal of Applied Microbiology, 108 (6): 1974-1981

Espinosa M F, Sancho A N, Mendoza L M, Mota C R, Verbyla M E (2020). Systematic review and meta-analysis of time-temperature pathogen inactivation. International Journal of Hygiene and Environmental Health, 230: 113595

Ferreira L C, Castro-Alférez M, Nahim-Granados S, Polo-López M I, Lucas M S, Li Puma G, Fernández-Ibáñez P (2020). Inactivation of water pathogens with solar photo-activated persulfate oxidation. Chemical Engineering Journal, 381: 122275

Fidjeland J, Nordin A, Pecson B M, Nelson K L, Vinnerås B (2015). Modeling the inactivation of ascaris eggs as a function of ammonia concentration and temperature. Water Research, 83: 153-160

Foladori P, Cutrupi F, Segata N, Manara S, Pinto F, Malpei F, Bruni L, La Rosa G (2020). SARS-CoV-2 from faeces to wastewater treatment: What do we know? A review. Science of the Total Environment, 743: 140444

Font R, Gomez-Rico M F, Fullana A (2011). Skin effect in the heat and mass transfer model for sewage sludge drying. Separation and Purification Technology, 77(1): 146-161

Forbis-Stokes A A, O’Meara P F, Mugo W, Simiyu G M, Deshusses M A (2016). On-Site Fecal Sludge Treatment with the Anaerobic
Digestion Pasteurization Latrine. Environmental Engineering Science, 33(11): 898-906

Forster-Carneiro T, Riau V, Pérez M (2010). Mesophilic anaerobic digestion of sewage sludge to obtain class B biosolids: Microbiological methods development. Biomass and Bioenergy, 34(12): $1805-1812$

Gale P (2003). Using event trees to quantify pathogen levels on root crops from land application of treated sewage sludge. Journal of Applied Microbiology, 94(1): 35-47

Gale P (2005). Land application of treated sewage sludge: Quantifying pathogen risks from consumption of crops. Journal of Applied Microbiology, 98(2): 380-396

Gantzer C, Gaspard P, Galvez L, Huyard A, Dumouthier N, Schwartzbrod J (2001). Monitoring of bacterial and parasitological contamination during various treatment of sludge. Water Research, 35(16): 3763-3770

Gaviria-Figueroa A, Preisner E C, Hoque S, Feigley C E, Norman R S (2019). Emission and dispersal of antibiotic resistance genes through bioaerosols generated during the treatment of municipal sewage. Science of the Total Environment, 686: 402-412

Ge D, Dong Y, Zhang W, Yuan H, Zhu N (2020). A novel $\mathrm{Fe}^{2+}$ / persulfate/tannic acid process with strengthened efficacy on enhancing waste activated sludge dewaterability and mechanism insight. Science of the Total Environment, 733: 139146

Gil A, Siles J A, Martín M A, Chica A F, Estévez-Pastor F S, ToroBaptista E (2018). Effect of microwave pretreatment on semicontinuous anaerobic digestion of sewage sludge. Renewable Energy, 115: 917-925

Goberna M, Simón P, Hernández M T, García C (2018). Prokaryotic communities and potential pathogens in sewage sludge: Response to wastewaster origin, loading rate and treatment technology. Science of the Total Environment, 615: 360-368

Gomes L A, Santos A F, Pinheiro C T, Góis J C, Quina M J (2020). Screening of waste materials as adjuvants for drying sewage sludge based on environmental, technical and economic criteria. Journal of Cleaner Production, 259: 120927

Graff J, Ticehurst J, Flehmig B (1993). Detection of hepatitis A virus in sewage sludge by antigen capture polymerase chain reaction. Applied and Environmental Microbiology, 59(10): 3165-3170

Grübel K, Suschka J (2015). Hybrid alkali-hydrodynamic disintegration of waste-activated sludge before two-stage anaerobic digestion process. Environmental Science and Pollution Research International, 22(10): 7258-7270

Guajardo-Leiva S, Chnaiderman J, Gaggero A, Díez B (2020). Metagenomic Insights into the sewage RNA virosphere of a large city. Viruses, 12(9): 1050

Hait S, Tare V (2011). Optimizing vermistabilization of waste activated sludge using vermicompost as bulking material. Waste Management (New York, N.Y.), 31(3): 502-511

Hamilton K A, Haas C N (2016). Critical review of mathematical approaches for quantitative microbial risk assessment (QMRA) of Legionella in engineered water systems: research gaps and a new framework. Environmental Science. Water Research \& Technology, 2(4): 599-613

Hamilton K A, Hamilton M T, Johnson W, Jjemba P, Bukhari Z, LeChevallier M, Haas C N, Gurian P L (2019). Risk-based critical 
concentrations of Legionella pneumophila for indoor residential water uses. Environmental Science \& Technology, 53(8): 4528-4541

Han Y P, Li L, Wang Y, Ma J W, Li P Y, Han C, Liu J X (2021). Composition, dispersion, and health risks of bioaerosols in wastewater treatment plants: A review. Frontiers of Environmental Science \& Engineering, 15(3): 16

Hansen J J, Warden P S, Margolin A B (2007). Inactivation of adenovirus type 5 , rotavirus Wa and male specific coliphage (MS2) in biosolids by lime stabilization. International Journal of Environmental Research and Public Health, 4(1): 61-67

Hong S M, Park J K, Lee Y O (2004). Mechanisms of microwave irradiation involved in the destruction of fecal coliforms from biosolids. Water Research, 38(6): 1615-1625

Hong S M, Park J K, Teeradej N, Lee Y O, Cho Y K, Park C H (2006). Pretreatment of sludge with microwaves for pathogen destruction and improved anaerobic digestion performance. Water Environment Research: A Research Publication of the Water Environment Federation, 78(1): 76-83

Hu S, Zhao W, Hu J, Liu B, Wang D, Zhu Q, Yang J, Hou H (2021). Integration of electrochemical and calcium hypochlorite oxidation for simultaneous sludge deep dewatering, stabilization and phosphorus fixation. Science of the Total Environment, 750: 141408

Hu Y, Wang F, Lv G, Chi Y (2019). Enhancing the biogas production of sludge anaerobic digestion by a combination of zero-valent iron foil and persulfate. Energy \& Fuels, 33(8): 7436-7442

Huang J, Elektorowicz M, Oleszkiewicz J A (2008). Dewatering and disinfection of aerobic and anaerobic sludge using an electrokinetic (EK) system. Water Science and Technology: A Journal of the International Association on Water Pollution Research, 57(2): 231236

Huang K, Mao Y, Zhao F, Zhang X X, Ju F, Ye L, Wang Y, Li B, Ren H, Zhang T (2018). Free-living bacteria and potential bacterial pathogens in sewage treatment plants. Applied Microbiology and Biotechnology, 102(5): 2455-2464

Huang K, Xia H, Zhang Y, Li J, Cui G, Li F, Bai W, Jiang Y, Wu N (2020). Elimination of antibiotic resistance genes and human pathogenic bacteria by earthworms during vermicomposting of dewatered sludge by metagenomic analysis. Bioresource Technology, 297: 122451

Inglis G D, McAllister T A, Larney F J, Topp E (2010). Prolonged survival of Campylobacter species in bovine manure compost. Applied and Environmental Microbiology, 76(4): 1110-1119

Iranpour R, Cox H H J (2006). Recurrence of fecal coliforms and Salmonella species in biosolids following thermophilic anaerobic digestion. Water Environment Research: A Research Publication of the Water Environment Federation, 78(9): 1005-1012

Iranpour R, Cox H H J (2007). Evaluation of thermophilic anaerobic digestion processes for full-scale Class A biosolids disinfection at Hyperion Treatment Plant. Biotechnology and Bioengineering, 97 (1): 19-39

Jafari M, Botte G G (2021). Electrochemical treatment of sewage sludge and pathogen inactivation. Journal of Applied Electrochemistry, 51 (1): 119-130

Jahne M A, Brinkman N E, Keely S P, Zimmerman B D, Wheaton E A, Garland J L (2020). Droplet digital PCR quantification of norovirus and adenovirus in decentralized wastewater and graywater collections: Implications for onsite reuse. Water Research, 169: 115213

Jebri S, Hmaied F, Lucena F, Saavedra M E, Yahya M, Hamdi M (2014). A comparison of two extraction methods for the detection of Enteroviruses in raw sludge. Journal of Virological Methods, 200: 15

Jin B, Niu J, Zhang J, Niu J, Zhou P, Dai J, Li N, Tao H, Ma Z, Zhang Z (2020). Response of extracellular polymeric substances and enzymatic activity to salinity for the waste activated sludge anaerobic fermentation process. Bioprocess and Biosystems Engineering, 43 (4): 737-745

Ju F, Lau F, Zhang T (2017). Linking Microbial Community, Environmental Variables, and Methanogenesis in Anaerobic Biogas Digesters of Chemically Enhanced Primary Treatment Sludge. Environmental Science \& Technology, 51(7): 3982-3992

Ju F, Li B, Ma L, Wang Y, Huang D, Zhang T (2016). Antibiotic resistance genes and human bacterial pathogens: Co-occurrence, removal, and enrichment in municipal sewage sludge digesters. Water Research, 91: 1-10

Jyoti A, Vajpayee P, Singh G, Patel C B, Gupta K C, Shanker R (2011). Identification of environmental reservoirs of nontyphoidal salmonellosis: Aptamer-assisted bioconcentration and subsequent detection of salmonella typhimurium by quantitative polymerase chain reaction. Environmental Science \& Technology, 45(20): 8996-9002

Kabrick R M, Jewell W J (1982). Fate of pathogens in thermophilic aerobic sludge digestion. Water Research, 16(6): 1051-1060

Kearney T E, Larkin M J, Levett P N (1993). The effect of slurry storage and anaerobic digestion on survival of pathogenic bacteria. Journal of Applied Bacteriology, 74(1): 86-93

Kelessidis A, Stasinakis A S (2012). Comparative study of the methods used for treatment and final disposal of sewage sludge in European countries. Waste Management (New York, N.Y.), 32(6): 1186-1195

Kennedy N A, Walker A W, Berry S H, Duncan S H, Farquarson F M, Louis P, Thomson J M, Satsangi J, Flint H J, Parkhill J, Lees C W, Hold G L, and the UK IBD Genetics Consortium (2014). The impact of different DNA extraction kits and laboratories upon the assessment of human gut microbiota composition by $16 \mathrm{~S}$ rRNA gene sequencing. PLoS One, 9(2): e88982

Khwairakpam M, Bhargava R (2009). Vermitechnology for sewage sludge recycling. Journal of Hazardous Materials, 161(2-3): 948-954

Kim T H, Lee M, Park C (2011). Gamma ray irradiation for sludge solubilization and biological nitrogen removal. Radiation Physics and Chemistry, 80(12): 1386-1390

Kong F E, Deighton M A, Thurbon N A, Smith S R, Rouch D A (2018). Cryptosporidium parvum decay during air drying and stockpiling of mesophilic anaerobically digested sewage sludge in a simulation experiment and oocyst counts in sludge collected from operational treatment lagoons in Victoria, Australia. Journal of Water and Health, 16(3): 435-448

Lagier J C, Armougom F, Million M, Hugon P, Pagnier I, Robert C, Bittar F, Fournous G, Gimenez G, Maraninchi M, Trape J F, Koonin E V, La Scola B, Raoult D (2012). Microbial culturomics: paradigm shift in the human gut microbiome study. Clinical Microbiology and Infection: The Official Publication of the European Society of Clinical Microbiology and Infectious Diseases, 18(12): 1185-1193 
Lammerding A M (2006). Modeling and risk assessment for Salmonella in meat and poultry. Journal of AOAC International, 89(2): 543-552

Lau C H F, Li B, Zhang T, Tien Y C, Scott A, Murray R, Sabourin L, Lapen D R, Duenk P, Topp E (2017). Impact of pre-application treatment on municipal sludge composition, soil dynamics of antibiotic resistance genes, and abundance of antibiotic-resistance genes on vegetables at harvest. Science of the Total Environment, 587-588: 214-222

Lei Q, Zheng J, Ma J, Wang X, Wu Z, Wang Z (2020). Simultaneous solid-liquid separation and wastewater disinfection using an electrochemical dynamic membrane filtration system. Environmental Research, 180: 108861

Levantesi C, Beimfohr C, Blanch A R, Carducci A, Gianico A, Lucena F, Tomei M C, Mininni G (2015). Hygienization performances of innovative sludge treatment solutions to assure safe land spreading. Environmental Science and Pollution Research International, 22(10): 7237-7247

Lewis D L, Gattie D K (2002). Pathogen risks from applying sewage sludge to land. Environmental Science \& Technology, 36(13): 286A$293 \mathrm{~A}$

Li B, Ju F, Cai L, Zhang T (2015). Profile and fate of bacterial pathogens in sewage treatment plants revealed by high-throughput metagenomic approach. Environmental Science \& Technology, 49(17): 10492-10502

Li D C, Gao J F, Zhang S J, Gao Y Q, Sun L X (2020a). Emergence and spread patterns of antibiotic resistance genes during two different aerobic granular sludge cultivation processes. Environment International, 137: 105540

Li J, Zhou L T, Zhang X Y, Xu C J, Dong L M, Yao M S (2016a). Bioaerosol emissions and detection of airborne antibiotic resistance genes from a wastewater treatment plant. Atmospheric Environment, 124: $404-412$

Li M, Yang Y, Lu Y, Zhang D, Liu Y, Cui X, Yang L, Liu R, Liu J, Li G, Qu J (2020b). Natural host-environmental media-human: A new potential pathway of COVID-19 outbreak. Engineering (Beijing, China), 6(10): 1085-1098

Li X, Li Y, Hong L (2016b). A novel self-assembling DNA nano chip for rapid detection of human Papillomavirus genes. PLoS One, 11(10): e0162975

Liao H, Lu X, Rensing C, Friman V P, Geisen S, Chen Z, Yu Z, Wei Z, Zhou S, Zhu Y (2018). Hyperthermophilic composting accelerates the removal of antibiotic resistance genes and mobile genetic elements in sewage sludge. Environmental Science \& Technology, 52(1): 266-276

Liu S, Zhu N, Li L Y (2011). The one-stage autothermal thermophilic aerobic digestion for sewage sludge treatment. Chemical Engineering Journal, 174(2-3): 564-570

Lizasoain A, Tort L F L, García M, Gillman L, Alberti A, Leite J P G, Miagostovich M P, Pou S A, Cagiao A, Razsap A, Huertas J, Berois M, Victoria M, Colina R (2018). Human enteric viruses in a wastewater treatment plant: Evaluation of activated sludge combined with UV disinfection process reveals different removal performances for viruses with different features. Letters in Applied Microbiology, 66(3): 215-221

Lloret E, Pastor L, Martínez-Medina A, Blaya J, Pascual J A (2012). Evaluation of the removal of pathogens included in the Proposal for a
European Directive on spreading of sludge on land during autothermal thermophilic aerobic digestion (ATAD). Chemical Engineering Journal, 198-199: 171-179

Lloret E, Pastor L, Pradas P, Pascual J A (2013). Semi full-scale thermophilic anaerobic digestion (TAnD) for advanced treatment of sewage sludge: Stabilization process and pathogen reduction. Chemical Engineering Journal, 232: 42-50

López A, Rodríguez-Chueca J, Mosteo R, Gómez J, Ormad M P (2020). Microbiological quality of sewage sludge after digestion treatment: A pilot scale case of study. Journal of Cleaner Production, 254: 120101

Lu F, Hu T Y, Wei S Y, Shao L M, He P J (2021). Bioaerosolization behavior along sewage sludge biostabilization. Frontiers of Environmental Science \& Engineering, 15(3): 45

Lu X, Zhang X X, Wang Z, Huang K, Wang Y, Liang W, Tan Y, Liu B, Tang $J$ (2015). Bacterial pathogens and community composition in advanced sewage treatment systems revealed by metagenomics analysis based on high-throughput sequencing. PLoS One, 10(5): e0125549

Lung A J, Lin C M, Kim J M, Marshall M R, Nordstedt R, Thompson N P, Wei C I (2001). Destruction of Escherichia coli O157:H7 and Salmonella enteritidis in cow manure composting. Journal of Food Protection, 64(9): 1309-1314

Luukkonen T, Prokkola H, Pehkonen S O (2020). Peracetic acid for conditioning of municipal wastewater sludge: Hygienization, odor control, and fertilizing properties. Waste Management (New York, N. Y.), 102: 371-379

Lv B, Xing M, Yang J (2018). Exploring the effects of earthworms on bacterial profiles during vermicomposting process of sewage sludge and cattle dung with high-throughput sequencing. Environmental Science and Pollution Research International, 25(13): 12528-12537

Magri M E, Fidjeland J, Jönsson H, Albihn A, Vinnerås B (2015). Inactivation of adenovirus, reovirus and bacteriophages in fecal sludge by $\mathrm{pH}$ and ammonia. Science of the Total Environment, 520: 213-221

Major N, Schierstaedt J, Jechalke S, Nesme J, Ban S G, Černe M, Sørensen S J, Ban D, Schikora A (2020). Composted Sewage Sludge Influences the Microbiome and Persistence of Human Pathogens in Soil. Microorganisms, 8(7): 1020

Mandilara G, Mavridou A, Lambiri M, Vatopoulos A, Rigas F (2006). The use of bacteriophages for monitoring the microbiological quality of sewage sludge. Environmental Technology, 27(4): 367-375

Maqbool T, Cho J, Hur J (2019). Improved dewaterability of anaerobically digested sludge and compositional changes in extracellular polymeric substances by indigenous persulfate activation. Science of the Total Environment, 674: 96-104

Martín-Díaz J, Lucena F, Blanch A R, Jofre J (2020). Review: Indicator bacteriophages in sludge, biosolids, sediments and soils. Environmental Research, 182: 109133

Mawioo P M, Garcia H A, Hooijmans C M, Velkushanova K, Simonič M, Mijatović I, Brdjanovic D (2017). A pilot-scale microwave technology for sludge sanitization and drying. Science of the Total Environment, 601-602: 1437-1448

Mehta C M, Palni U, Franke-Whittle I H, Sharma A K (2014). Compost: its role, mechanism and impact on reducing soil-borne plant diseases. Waste Management (New York, N.Y.), 34(3): 607-622

Mignotte-Cadiergues B, Gantzer C, Schwartzbrod L (2002). Evaluation 
of bacteriophages during the treatment of sludge. Water Science and Technology: A Journal of the International Association on Water Pollution Research, 46(10): 189-194

Millner P D, Powers K E, Enkiri N K, Burge W D (1987). Microbially mediated growth suppression and death of salmonella in composted sewage sludge. Microbial Ecology, 14(3): 255-265

Min Jang H, Choi S, Shin J, Kan E, Mo Kim Y (2019). Additional reduction of antibiotic resistance genes and human bacterial pathogens via thermophilic aerobic digestion of anaerobically digested sludge. Bioresource Technology, 273: 259-268

Mocé-Llivina L, Muniesa M, Pimenta-Vale H, Lucena F, Jofre J (2003). Survival of bacterial indicator species and bacteriophages after thermal treatment of sludge and sewage. Applied and Environmental Microbiology, 69(3): 1452-1456

Moletta-Denat M, Bru-Adan V, Delgenes J P, Hamelin J, Wéry N, Godon J J (2010). Selective microbial aerosolization in biogas demonstrated by quantitative PCR. Bioresource Technology, 101 (19): 7252-7257

Mondal T, Rouch D A, Thurbon N, Smith S R, Deighton M A (2015). Factors affecting decay of Salmonella Birkenhead and coliphage MS2 during mesophilic anaerobic digestion and air drying of sewage sludge. Journal of Water and Health, 13(2): 459-472

Monpoeho S, Maul A, Bonnin C, Patria L, Ranarijaona S, Billaudel S, Ferré V (2004). Clearance of human-pathogenic viruses from sludge: study of four stabilization processes by real-time reverse transcription-PCR and cell culture. Applied and Environmental Microbiology, 70(9): 5434-5440

Monroy F, Aira M, Domínguez J (2009). Reduction of total coliform numbers during vermicomposting is caused by short-term direct effects of earthworms on microorganisms and depends on the dose of application of pig slurry. Science of the Total Environment, 407(20): 5411-5416

Mosquera-Losada M R, Rigueiro-Rodríguez A, Ferreiro-Domínguez N (2012). Residual effects of lime and sewage sludge inputs on soil fertility and tree and pasture production in a Pinus radiata D. Don silvopastoral system established in a very acidic soil. Agriculture, Ecosystems \& Environment, 161: 165-173

Naidoo D, Appleton C C, Archer C E, Foutch G L (2019). The inactivation of Ascaris suum eggs by short exposure to high temperatures. Journal of Water, Sanitation, and Hygiene for Development : a Journal of the International Water Association, 9 (1): 19-27

Navab Daneshmand T, Beton R, Hill R J, Gehr R, Frigon D (2012). Inactivation mechanisms of bacterial pathogen indicators during electro-dewatering of activated sludge biosolids. Water Research, 46 (13): 3999-4008

Navarro I, Jiménez B, Lucario S, Cifuentes E (2009). Application of Helminth ova infection dose curve to estimate the risks associated with biosolid application on soil. Journal of Water and Health, 7(1): 31-44

Orzi V, Scaglia B, Lonati S, Riva C, Boccasile G, Alborali G L, Adani F (2015). The role of biological processes in reducing both odor impact and pathogen content during mesophilic anaerobic digestion. Science of the Total Environment, 526: 116-126

Paez-Rubio T, Ramarui A, Sommer J, Xin H, Anderson J, Peccia J (2007). Emission rates and characterization of aerosols produced during the spreading of dewatered class B biosolids. Environmental Science \& Technology, 41(10): 3537-3544

Pandey P K, Soupir M L (2011). Escherichia coli inactivation kinetics in anaerobic digestion of dairy manure under moderate, mesophilic and thermophilic temperatures. AMB Express, 1(1): 18

Pecson B M, Barrios J A, Jiménez B E, Nelson K L (2007). The effects of temperature, $\mathrm{pH}$, and ammonia concentration on the inactivation of Ascaris eggs in sewage sludge. Water Research, 41(13): 2893-2902

Pietronave S, Fracchia L, Rinaldi M, Martinotti M G (2004). Influence of biotic and abiotic factors on human pathogens in a finished compost. Water Research, 38(8): 1963-1970

Plachá I, Venglovský J, Maková Z, Martinéz J (2008). The elimination of Salmonella typhimurium in sewage sludge by aerobic mesophilic stabilization and lime hydrated stabilization. Bioresource Technology, 99(10): 4269-4274

Prado T, Gaspar A M C, Miagostovich M P (2014). Detection of enteric viruses in activated sludge by feasible concentration methods. Brazilian Journal of Microbiology, 45(1): 343-349

Pritchard D L, Penney N, McLaughlin M J, Rigby H, Schwarz K (2010). Land application of sewage sludge (biosolids) in Australia: Risks to the environment and food crops. Water Science and Technology: A Journal of the International Association on Water Pollution Research, 62(1): 48-57

Quince C, Walker A W, Simpson J T, Loman N J, Segata N (2017). Shotgun metagenomics, from sampling to analysis. Nature Biotechnology, 35(9): 833-844

Rahube T O, Marti R, Scott A, Tien Y C, Murray R, Sabourin L, Zhang Y, Duenk P, Lapen D R, Topp E (2014). Impact of fertilizing with raw or anaerobically digested sewage sludge on the abundance of antibiotic-resistant coliforms, antibiotic resistance genes, and pathogenic bacteria in soil and on vegetables at harvest. Applied and Environmental Microbiology, 80(22): 6898-6907

Rajagopal R, Massé D I, Singh G (2013). A critical review on inhibition of anaerobic digestion process by excess ammonia. Bioresource Technology, 143: 632-641

Ranković B, Sagatova A, Vujcic I, Masic S, Veljovic D, Pavicevic V, Kamberovic Z (2020). Utilization of gamma and e-beam irradiation in the treatment of waste sludge from a drinking water treatment plant. Radiation Physics and Chemistry, 177: 109177

Rizzo L, Manaia C, Merlin C, Schwartz T, Dagot C, Ploy M C, Michael I, Fatta-Kassinos D (2013). Urban wastewater treatment plants as hotspots for antibiotic resistant bacteria and genes spread into the environment: A review. Science of the Total Environment, 447: 345360

Robledo-Mahón, Gómez-Silván C, Andersen G L, Calvo C, Aranda E (2020). Assessment of bacterial and fungal communities in a fullscale thermophilic sewage sludge composting pile under a semipermeable cover. Bioresource Technology, 298: 122550

Robledo-Mahón T, Silva-Castro G A, Kuhar U, Jamnikar-Ciglenečki U, Barlič-Maganja D, Aranda E, Calvo C (2019). Effect of composting under semipermeable film on the sewage sludge virome. Microbial Ecology, 78(4): 895-903

Romdhana M H, Lecomte D, Ladevie B, Sablayrolles C (2009). Monitoring of pathogenic microorganisms contamination during heat drying process of sewage sludge. Process Safety and Environmental Protection, 87(6): 377-386 
Rumky J, Visigalli S, Turolla A, Gelmi E, Necibi C, Gronchi P, Sillanpää M, Canziani R (2020). Electro-dewatering treatment of sludge: Assessment of the influence on relevant indicators for disposal in agriculture. Journal of Environmental Management, 268: 110689

Sado K, Ayusawa D, Enomoto A, Suganuma T, Oshimura M, Sato K, Koyama H (2001). Identification of a mutated DNA ligase IV gene in the X-ray-hypersensitive mutant SX10 of mouse FM3A cells. Journal of Biological Chemistry, 276(13): 9742-9748

Sahlström L (2003). A review of survival of pathogenic bacteria in organic waste used in biogas plants. Bioresource Technology, 87(2): 161-166

Sano D, Fukushi K, Yoshida Y, Omura T (2003). Detection of enteric viruses in municipal sewage sludge by a combination of the enzymatic virus elution method and RT-PCR. Water Research, 37 (14): 3490-3498

Santos A F, Santos C P, Matos A M, Cardoso O, Quina M J (2020). Effect of thermal drying and chemical treatments with wastes on microbiological contamination indicators in sewage sludge. Microorganisms, 8(3): 376

Schlosser O, Huyard A, Cartnick K, Yañez A, Catalán V, Do Quang Z (2009). Bioaerosol in composting facilities: Occupational health risk assessment. Water Environment Research: A Research Publication of the Water Environment Federation, 81(9): 866-877

Schlosser O, Robert S, Debeaupuis C, Huyard A (2018). Inhalable dust as a marker of exposure to airborne biological agents in composting facilities. Waste Management (New York, N.Y.), 81: 78-87

Schöniger-Hekele M, Petermann D, Weber B, Müller C (2007). Tropheryma whipplei in the environment: survey of sewage plant influxes and sewage plant workers. Applied and Environmental Microbiology, 73(6): 2033-2035

Sen B, Chandra T S (2009). Do earthworms affect dynamics of functional response and genetic structure of microbial community in a lab-scale composting system? Bioresource Technology, 100(2): 804-811

Shannon K E, Lee D Y, Trevors J T, Beaudette L A (2007). Application of real-time quantitative PCR for the detection of selected bacterial pathogens during municipal wastewater treatment. Science of the Total Environment, 382(1): 121-129

Sidhu J, Gibbs R A, Ho G E, Unkovich I (2001). The role of indigenous microorganisms in suppression of Salmonella regrowth in composted biosolids. Water Research, 35(4): 913-920

Simmons F J, Xagoraraki I (2011). Release of infectious human enteric viruses by full-scale wastewater utilities. Water Research, 45(12): 3590-3598

Soobhany N, Mohee R, Garg V K (2017). Inactivation of bacterial pathogenic load in compost against vermicompost of organic solid waste aiming to achieve sanitation goals: A review. Waste Management (New York, N.Y.), 64: 51-62

Soueidan H, Schmitt L A, Candresse T, Nikolski M (2015). Finding and identifying the viral needle in the metagenomic haystack: trends and challenges. Frontiers in Microbiology, 5: 739

Su J Q, Wei B, Ou-Yang W Y, Huang F Y, Zhao Y, Xu H J, Zhu Y G (2015). Antibiotic resistome and its association with bacterial communities during sewage sludge composting. Environmental Science \& Technology, 49(12): 7356-7363

Sutherland K P, Porter J W, Turner J W, Thomas B J, Looney E E, Luna
T P, Meyers M K, Futch J C, Lipp E K (2010). Human sewage identified as likely source of white pox disease of the threatened Caribbean elkhorn coral, Acropora palmata. Environmental Microbiology, 12(5): 1122-1131

Swati A, Hait S (2018). A Comprehensive Review of the Fate of Pathogens during Vermicomposting of Organic Wastes. Journal of Environmental Quality, 47(1): 16-29

Tanner B D, Brooks J P, Gerba C P, Haas C N, Josephson K L, Pepper I L (2008). Estimated occupational risk from bioaerosols generated during land application of class B biosolids. Journal of Environmental Quality, 37(6): 2311-2321

Tong J, Fang P, Zhang J, Wei Y, Su Y, Zhang Y (2019). Microbial community evolution and fate of antibiotic resistance genes during sludge treatment in two full-scale anaerobic digestion plants with thermal hydrolysis pretreatment. Bioresource Technology, 288: 121575

Tong M, Liu F, Dong Q, Ma Z, Liu W (2020). Magnetic $\mathrm{Fe}_{3} \mathrm{O}_{4}$ deposited flower-like $\mathrm{MoS}_{2}$ nanocomposites for the Fenton-like Escherichia coli disinfection and diclofenac degradation. Journal of Hazardous Materials, 385: 121604

Traub F, Spillmann S K, Wyler R (1986). Method for determining virus inactivation during sludge treatment processes. Applied and Environmental Microbiology, 52(3): 498-503

Tsitsifli S, Tsoukalas D S (2021). Water Safety Plans and HACCP implementation in water utilities around the world: benefits, drawbacks and critical success factors. Environmental Science and Pollution Research International, 28(15): 18837-18849

Uma Rani R, Adish Kumar S, Kaliappan S, Yeom I, Rajesh Banu J (2013). Impacts of microwave pretreatments on the semi-continuous anaerobic digestion of dairy waste activated sludge. Waste Management (New York, N.Y.), 33(5): 1119-1127

USEPA (1994). Land application of sewage sludge: A guide for land appliers on the requirements of the federal standard for the use or disposal of sewage sludge, 40 CFR Part 503. USEPA, Washington, DC. EPA/831-B-93-002b.

Valderrama C, Granados R, Cortina J L (2013). Stabilisation of dewatered domestic sewage sludge by lime addition as raw material for the cement industry: Understanding process and reactor performance. Chemical Engineering Journal, 232: 458-467

Van Abel N, Schoen M E, Kissel J C, Meschke J S (2017). Comparison of risk predicted by multiple norovirus dose-response models and implications for quantitative microbial risk Assessment. Risk Analysis: An Official Publication of the Society for Risk Analysis, 37(2): 245-264

Venieri D, Karapa A, Panagiotopoulou M, Gounaki I (2020). Application of activated persulfate for the inactivation of fecal bacterial indicators in water. Journal of Environmental Management, 261: 110223

Viau E, Bibby K, Paez-Rubio T, Peccia J (2011). Toward a consensus view on the infectious risks associated with land application of sewage sludge. Environmental Science \& Technology, 45(13): 54595469

Viau E, Peccia J (2009). Survey of wastewater indicators and human pathogen genomes in biosolids produced by Class A and Class B stabilization treatments. Applied and Environmental Microbiology, 75(1): $164-174$ 
Walker A W, Martin J C, Scott P, Parkhill J, Flint H J, Scott K P (2015). 16S rRNA gene-based profiling of the human infant gut microbiota is strongly influenced by sample processing and PCR primer choice. Microbiome, 3(1): 26

Wang J, Wang J (2007). Application of radiation technology to sewage sludge processing: A review. Journal of Hazardous Materials, 143(1-2): 2-7

Wang M, Chen H, Liu S, Xiao L (2021). Removal of pathogen and antibiotic resistance genes from waste activated sludge by different pre-treatment approaches. Science of the Total Environment, 763: 143014

Wang M L, Li R Y, Zhao Q (2019). Distribution and removal of antibiotic resistance genes during anaerobic sludge digestion with alkaline, thermal hydrolysis and ultrasonic pretreatments. Frontiers of Environmental Science \& Engineering, 13(3): 43

Wang W, Wang H, Li G, Wong P K, An T (2020). Visible light activation of persulfate by magnetic hydrochar for bacterial inactivation: Efficiency, recyclability and mechanisms. Water Research, 176: 115746

Ward R L, Ashley C S (1978). Heat inactivation of enteric viruses in dewatered wastewater sludge. Applied and Environmental Microbiology, 36(6): 898-905

Watanabe T, Sano D, Omura T (2002). Risk evaluation for pathogenic bacteria and viruses in sewage sludge compost. Water Science and Technology: A Journal of the International Association on Water Pollution Research, 46(11-12): 325-330

Watcharasukarn M, Kaparaju P, Steyer J P, Krogfelt K A, Angelidaki I (2009). Screening Escherichia coli, Enterococcus faecalis, and Clostridium perfringens as indicator organisms in evaluating pathogen-reducing capacity in biogas plants. Microbial Ecology, 58(2): 221-230

Wéry N, Lhoutellier C, Ducray F, Delgenès J P, Godon J J (2008). Behaviour of pathogenic and indicator bacteria during urban wastewater treatment and sludge composting, as revealed by quantitative PCR. Water Research, 42(1-2): 53-62

Wichuk K M, Mccartney D (2007). A review of the effectiveness of current time-temperature regulations on pathogen inactivation during composting. Journal of Environmental Engineering and Science, 6(5): 573-586

Wong J W C, Selvam A (2009). Reduction of indicator and pathogenic microorganisms in pig manure through fly ash and lime addition during alkaline stabilization. Journal of Hazardous Materials, 169(1-3): 882-889

Wong K, Onan B M, Xagoraraki I (2010). Quantification of enteric viruses, pathogen indicators, and Salmonella bacteria in Class B anaerobically digested biosolids by culture and molecular methods. Applied and Environmental Microbiology, 76(19): 6441-6448

Wu Y, Jiang Y, Ke G, Liu Y (2017). Effect of gamma-ray irradiation on the dewaterability of waste activated sludge. Radiation Physics and Chemistry, 130: 164-170

Xu P, Zhang C, Mou X, Wang X C (2020). Bioaerosol in a typical municipal wastewater treatment plant: concentration, size distribution, and health risk assessment. Water Science and Technology: A Journal of the International Association on Water Pollution Research, 82(8): 1547-1559

Yan C, Wang R N, Zhao X Y (2021). Emission characteristics of bioaerosol and quantitative microbiological risk assessment for equipping individuals with various personal protective equipment in a WWTP. Chemosphere, 265: 129117

Yang G, Zhang G, Wang H (2015). Current state of sludge production, management, treatment and disposal in China. Water Research, 78: 60-73

Yang K, Li L, Wang Y, Xue S, Han Y, Liu J (2019). Airborne bacteria in a wastewater treatment plant: Emission characterization, source analysis and health risk assessment. Water Research, 149: 596-606

Yang W, Cai C, Dai X (2020). The potential exposure and transmission risk of SARS-CoV-2 through sludge treatment and disposal. Resources, Conservation and Recycling, 162: 105043

Ye L, Zhang T (2011). Pathogenic bacteria in sewage treatment plants as revealed by 454 pyrosequencing. Environmental Science \& Technology, 45(17): 7173-7179

Yenigün O, Demirel B (2013). Ammonia inhibition in anaerobic digestion: A review. Process Biochemistry, 48(5-6): 901-911

Yin F B, Li Z F, Saino M, Dong H M (2017). Performance of alkaline pretreatment on pathogens inactivation and sludge solubilization. International Journal of Agricultural and Biological Engineering, 10(2): 216-223

Yin Z, Hoffmann M, Jiang S (2018). Sludge disinfection using electrical thermal treatment: The role of ohmic heating. Science of the Total Environment, 615: 262-271

Yu B, Zheng G D, Wang X D, Wang M, Chen T B (2019a). Biodegradation of triclosan and triclocarban in sewage sludge during composting under three ventilation strategies. Frontiers of Environmental Science \& Engineering, 13(3): 41

Yu D T, He J Z, Zhang L M, Han L L (2019b). Viral metagenomics analysis and eight novel viral genomes identified from the Dushanzi mud Volcanic soil in Xinjiang, China. Journal of Soils and Sediments, 19(1): 81-90

Yu J, Xiao K, Yang J, Yu W, Pei K, Zhu Y, Wang J, Liang S, Hu J, Hou H, Liu B (2019c). Enhanced sludge dewaterability and pathogen inactivation by synergistic effects of zero-valent iron and ozonation. ACS Sustainable Chemistry \& Engineering, 7(1): 324-331

Yu R, Zhang S W, Chen Z K, Li C Y (2017). Isolation and application of predatory Bdellovibrio-and-like organisms for municipal waste sludge biolysis and dewaterability enhancement. Frontiers of Environmental Science \& Engineering, 11(1): 10

Yu W, Wen Q, Yang J, Xiao K, Zhu Y, Tao S, Lv Y, Liang S, Fan W, Zhu S, Liu B, Hou H, Hu J (2019d). Unraveling oxidation behaviors for intracellular and extracellular from different oxidants ( $\mathrm{HOCl}$ vs. $\mathrm{H}_{2} \mathrm{O}_{2}$ ) catalyzed by ferrous iron in waste activated sludge dewatering. Water Research, 148: 60-69

Yu Y, Chan W I, Liao P H, Lo K V (2010). Disinfection and solubilization of sewage sludge using the microwave enhanced advanced oxidation process. Journal of Hazardous Materials, 181(1-3): 1143-1147

Zaleski K J, Josephson K L, Gerba C P, Pepper I L (2005). Potential regrowth and recolonization of salmonellae and indicators in biosolids and biosolid-amended soil. Applied and Environmental Microbiology, 71(7): 3701-3708

Zaneti R N, Girardi V, Spilki F R, Mena K, Westphalen A P C, da Costa Colares E R, Pozzebon A G, Etchepare R G (2021). Quantitative 
microbial risk assessment of SARS-CoV-2 for workers in wastewater treatment plants. Science of the Total Environment, 754: 142163

Zeng Q, Zan F, Hao T, Biswal B K, Lin S, van Loosdrecht M C M, Chen G (2019). Electrochemical pretreatment for stabilization of waste activated sludge: Simultaneously enhancing dewaterability, inactivating pathogens and mitigating hydrogen sulfide. Water Research, 166: 115035

Zhang H, Xu L, Zhang Y F, Jiang M C (2016). The transformation of $\mathrm{PAHs}$ in the sewage sludge incineration treatment. Frontiers of Environmental Science \& Engineering, 10(2): 336-340

Zhang H, Zhang Z, Song J, Cai L, Yu Y, Fang H (2021). Foam shares antibiotic resistomes and bacterial pathogens with activated sludge in wastewater treatment plants. Journal of Hazardous Materials, 408: 124855

Zhang L, Chen Y, Ma C, Liu L, Pan J, Li B, Wu X, Wang Q (2020). Improving heavy metals removal, dewaterability and pathogen removal of waste activated sludge using enhanced chemical leaching. Journal of Cleaner Production, 271: 122512

Zhang T, Zhang M, Zhang X, Fang H H (2009). Tetracycline resistance genes and tetracycline resistant lactose-fermenting Enterobacteriaceae in activated sludge of sewage treatment plants. Environmental Science \& Technology, 43(10): 3455-3460

Zhao Q, Liu Y (2019). Is anaerobic digestion a reliable barrier for deactivation of pathogens in biosludge? Science of the Total Environment, 668: 893-902

Zimek Z (2020). Economical evaluation of radiation processing with high-intensity X-rays. Nukleonika, 65(3): 167-172

Zou X, Tang G, Zhao X, Huang Y, Chen T, Lei M, Chen W, Yang L, Zhu W, Zhuang L, Yang J, Feng Z, Wang D, Wang D, Shu Y (2017). Simultaneous virus identification and characterization of severe unexplained pneumonia cases using a metagenomics sequencing technique. Science China. Life Sciences, 60(3): 279-286 